Revista de Dialectología y Tradiciones Populares, vol. LXXIII, n. ${ }^{\circ}$, pp. 493-524, julio-diciembre 2018,

ISSN: 0034-7981, eISSN: 1988-8457,

https://doi.org/10.3989/rdtp.2018.02.011

\title{
Viajeros étnicos, gestos exóticos y encuentros esporádicos: los tours mayas en Los Altos de Chiapas*
}

\section{Ethnic Travellers, Exotic Gestures, and Sporadic Encounters: The Mayan Tours in Los Altos de Chiapas}

\author{
Eugenia Bayona Escat ${ }^{1}$ \\ Universidad de Valencia
}

\section{RESUMEN}

Este trabajo reflexiona sobre la interacción turista/anfitrión en los tours étnicos promovidos en la región Altos Tsotsil-Tseltal Chiapas, México. Las agencias turísticas promueven diferentes encuentros de los turistas con la población indígena donde se espera que los primeros cumplan con sus expectativas sobre el Otro exótico y los segundos se acoplen a los imaginarios que corren sobre sí mismos. Aquí, al contrario, interesa analizar un espacio turístico en constante construcción con la observación de tres lugares de protagonismo indígena: un mercado indígena en San Cristóbal de Las Casas, una iglesia en San Juan Chamula y una casa de tejedoras en Zinacantán, donde los roles sociales del visitante y del anfitrión se van definiendo en la interacción. El estudio señala que estos ámbitos de interacción turística son lugares de reproducción de imaginarios turísticos y se convierten a la vez en espacios de conquista y legitimación por parte de la población anfitriona.

Palabras clave: Turismo étnico; Espacio turístico; Consumo cultural; Imaginarios turísticos; Los Altos de Chiapas.

\section{SUMMARY}

This work reflects on the tourist/host interaction in ethnic tours promoted in the region Altos Tsotsil-Tseltal Chiapas, Mexico. Tourist agencies promote different encounters between tourists and the indigenous population where the former are expected to meet expectations of an exotic Other and the latter to conform with the imaginaries that circulate about them. By contrast, my interest here lies in analysing a tourist area in a constant state of construction, observing the indigenous role in three different places: an Indian market in San Cristobal de Las Casas, a church in San Juan Chamula and a Zinacantan weavers' house, where the social roles of visitor and host are defined in the interaction. The study indicates that such areas of tourist interaction are places

* El trabajo forma parte del proyecto I+D: Turismo étnico y rituales new age en Los Altos de Chiapas, México de la Generalitat Valenciana (GV2015/038) y da continuidad al proyecto precompetitivo: Consumo cultural, turismo étnico y espiritualidad new age en San Cristóbal de Las Casas, México (UV-INV-PRECOMP12-80547) de la Universidad de Valencia. Una primera versión de este trabajo fue presentada en el VI Congresso da Associação Portuguesa de Antropologia: Futuros Disputados, celebrado en la ciudad de Coímbra los días 2, 3 y 4 de junio de 2016.

${ }^{1}$ Correo electrónico: M.Eugenia.Bayona@uv.es. ORCID iD: <https://orcid.org/0000-0001-7579-7200>. 
where tourist imaginaries are reproduced and which, at the same time, become spaces of conquest and legitimation by the host population.

Keywords: Ethnic Tourism; Tourist Area; Cultural Consumption; Tourist Imaginaries; Los Altos de Chiapas.

\section{INTRODUCCION}

Cuando se habla de tours turísticos la imagen que deviene es una perspectiva en la que tanto el turista visitante como el anfitrión residente asumen una postura pasiva, casi siempre manipulada y construida por los medios de comunicación y por los prestadores de servicios como agencias y guías turísticos. En este sentido, numerosos estudios han puesto el foco de atención en cómo la actividad turística puede ser negativa para la población receptora puesto que resulta una realidad construida en la que acontecen tanto mercantilización como pérdida de la cultura autóctona local (Greenwood 1992; Smith 1992). Por su parte, desde el punto de vista del turista, las imágenes construidas con antelación y los imaginarios turísticos que cargan a sus espaldas pueden derivar en la búsqueda de una autenticidad inexistente y en la construcción de unos escenarios frontales que esconden el mundo trasero real que nunca alcanzan a vislumbrar (MacCannell 2003). La realidad puede ser muy diferente si ponemos el foco de atención en la propia interacción, en un espacio turístico en constante construcción por parte de turistas y anfitriones que componen y manipulan imaginarios diversos. Se parte de la base que el espacio turístico es un mundo específicamente creado para el ocio y entretenimiento en el que intervienen múltiples actores y no solo en el destino: agentes turísticos, publicistas de diversos medios de comunicación, prestadores de servicios y comerciantes, entre otros. No obstante, esta construcción puede derivar precisamente en la interacción de unos y otros con sus propias perspectivas sobre cómo debe ser el contacto. En otras palabras, lo que interesa es poner el punto central en las características del espacio de encuentro, diferente de antes de la llegada de los turistas, en el que se van creando, como señala Santana (1997: 62), una matriz común de significados.

Esto es especialmente significativo en el caso del denominado turismo étnico en el que los visitantes se acercan y observan la vida de esos Otros indígenas o nativos que viven en lugares remotos. En muchos casos, esta observación incluye la participación en algunos eventos locales como rituales, danzas o visitas a casas particulares para ejemplificar un mayor contacto con su tradición cultural (Smith 1992; Van den Berghe 1994; Santana 1997; MacCannell 2003). Cada día se incrementa más este tipo de turista que busca la autenticidad en otros lugares añorados como paraísos terrenales y en el que se busca cumplir con unos imaginarios sobre un Otro inexistente. Puesto que no hay aislamiento sino diferentes formas de estar insertado en el mundo global, la construcción de una etnicidad creada para el consumo es un foco de estudio interesante. Pone en tela de juicio que las construcciones esencialistas y atemporales del Otro se impongan fácilmente en los lugares de destino, para hacer hincapié en cómo los nuevos protagonistas actúan conforme a la realidad presente en la que están inmersos.

A partir de los tours turísticos que se promueven en la región Altos Tsotsil-Tseltal de Chiapas, este estudio indaga en cómo los actores implicados, visitantes y residen- 
tes, construyen narrativas turísticas en tres espacios de interacción: un mercado de artesanías con vendedores indígenas en la ciudad de San Cristóbal de Las Casas, una iglesia en San Juan Chamula con una gran condensación de actos y elementos rituales, y una casa/tienda de tejedoras en Zinacantán donde las mujeres exhiben la técnica del telar y exponen sus productos a la venta. En cada uno de estos espacios la interacción se presenta de manera diferente; hay contacto o mera observación, se desarrollan diversas estrategias de compra y venta dentro del consumo de personas, lugares y objetos, o se exhibe y se construye una autenticidad creada para el ocio y consumo turístico (Figura 1). Para el indígena la exhibición cultural está estrechamente vinculada a la supervivencia económica, a la vez que puede dar lugar a un empoderamiento político y social que merece ser indagado. Esto se refuerza por la conquista de espacios turísticos que sirven para la presentación social indígena. Por su parte, para el turista esa búsqueda de la autenticidad implica una experiencia corporal y sensorial, creando su propio concepto de autenticidad existencial, y en una experiencia constructiva e interactiva entre los que ven y los que son vistos (Cohen 1988; Graburn 1992; Wang 1999; Urry 2002).

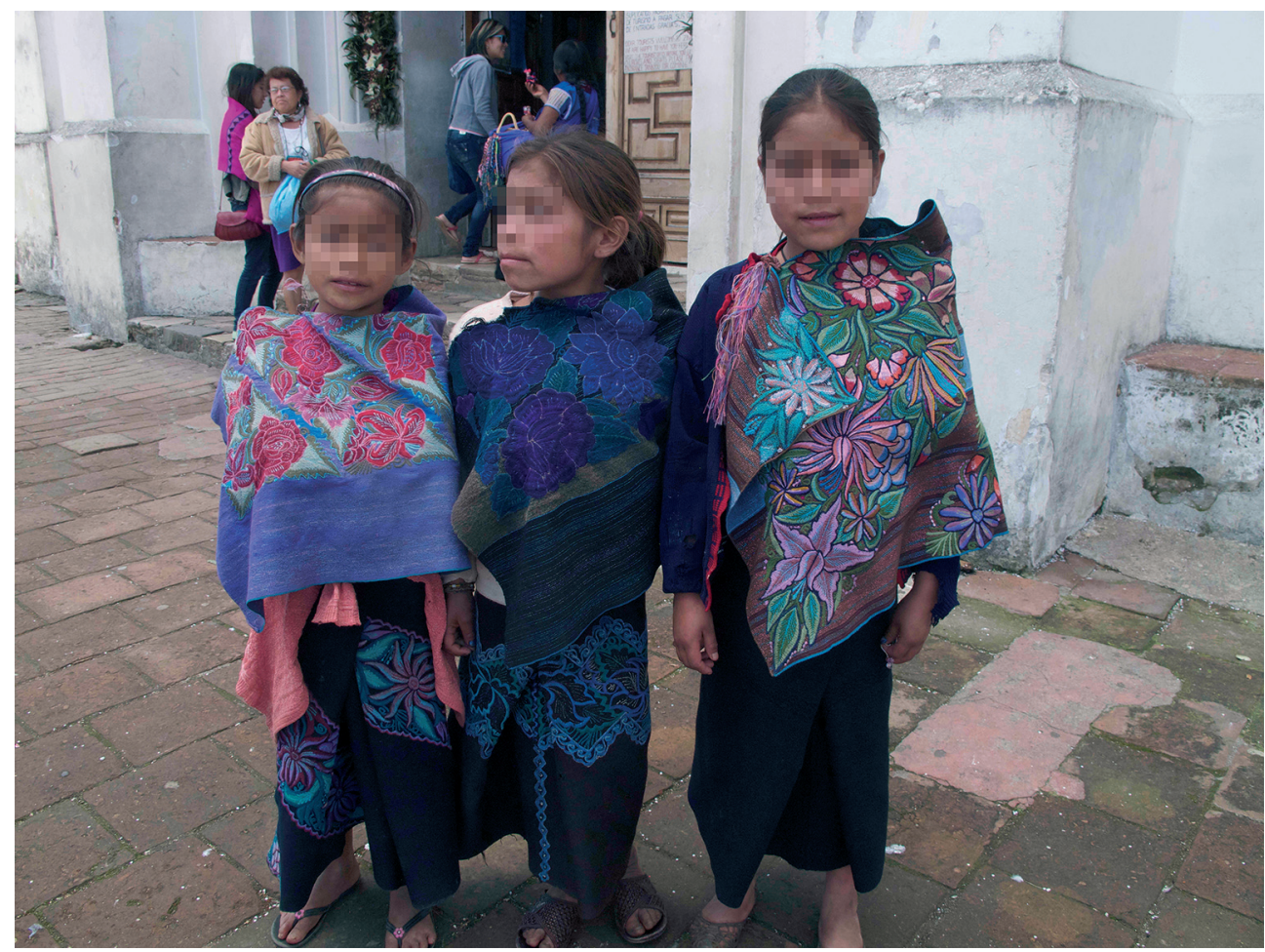

FIGURA 1.-Niñas zinacantecas posando para los turistas. Foto: Eugenia Bayona

En las páginas siguientes exploro en estos ámbitos de interacción entre visitante/ anfitrión como lugares turísticos en el que se producen encuentros esporádicos con 
una gran carga simbólica y cultural. El argumento central es que estos espacios turísticos sirven tanto para la experiencia turística como para el empoderamiento indígena; por un lado, son lugares donde se construyen significados trasnacionales a través de diversos imaginarios sobre el otro; se convierten además en ámbitos estratégicos para la invención y apropiación de la identidad y la cultura de los anfitriones. En ambos casos se propone poner el foco de atención en la forma como esos Otros son representados y se representan dentro de dinámicas globales y transnacionales.

Para desarrollar este tema utilizaré datos etnográficos de la investigación efectuada en la región Altos, especialmente en los tres lugares escogidos para el análisis. El trabajo de campo se realizó entre los años 2012 y 2015 con visitas al campo durante los meses de verano, con gran afluencia de turistas, y una estancia de tres meses de octubre a diciembre en el 2015. Mi sede principal fue la capital de San Cristóbal por ser el centro que coordina todos los servicios turísticos. Recopilé información promovida desde las instituciones públicas en agencias estatales y municipales, páginas web de la Secretaría de Turismo del Gobierno del Estado de Chiapas ${ }^{2}$ y datos censales sobre la afluencia del turismo proporcionada por el Instituto Nacional de Estadística, Geografía e Informática (INEGI). También consulté los folletos publicitarios, revistas, postales y páginas web de agencias de viajes, hoteles y restaurantes, la promoción turística de los museos, así como la publicidad en algunas tiendas artesanales y cooperativas indígenas.

Para conocer el desarrollo del turismo en la zona entrevisté a agentes locales en la Delegación de Turismo y en la Oficina de Turismo en San Cristóbal, así como a una antigua directora de la Secretaría de Turismo en la ciudad que me ofreció información relevante sobre los cambios políticos que influyen en la intervención y planificación del sector turístico en la zona. Se efectuaron entrevistas en profundidad, semiestructuradas e informales a informantes clave relacionados con el turismo: guías turísticos, transportistas, comerciantes y vendedores ambulantes o propietarios y trabajadores de servicios hoteleros y de restauración. Para el análisis del comercio de mercancías étnicas se realizaron entrevistas en profundidad a dos vendedoras indígenas que residen en la ciudad y otras entrevistas informales a mujeres vendedoras en los principales mercados de Santo Domingo y en los municipios indígenas. Se realizaron también 10 entrevistas semiestructuradas a mujeres mestizas y extranjeras que tienen tiendas de propiedad en las mejores calles y alrededor del Parque Central, así como a 5 mujeres indígenas integrantes de cooperativas o asociaciones indígenas. Por último, se realizaron entrevistas informales a tejedoras en los municipios de Aldama, San Andrés Larráinzar, Tenejapa y Zinacantán. La idea era entender las diferentes vías y estrategias que utilizan las productoras y vendedoras para su comercialización en un mercado local de artesanías cada vez más saturado.

Mucha de la información ha sido tomada de la observación a través de la participación en tours organizados por diferentes agencias turísticas, principalmente en las rutas oficiales que recorren los pueblos indígenas de Chamula y Zinacantán, pero también en otros viajes privados que amplían las visitas a municipios indígenas como Tenejapa o San Andrés Larráinzar, que incluye la visita al caracol Oventik sede de

\footnotetext{
${ }^{2}$ Véase: <http://www.turismochiapas.gob.mx/sectur/index.php >. Fecha de acceso: 15 ene. 2018.
} 
los zapatistas ${ }^{3}$. También participé en el tour del tranvía El Coleto que recorre la ciudad de San Cristóbal y ofrece información sobre los orígenes y evolución de la ciudad colonial, sin profundizar en la población indígena que habita actualmente en la ciudad. La participación en los tours hacia los municipios indígenas me permitió entrevistar a los guías y escuchar la información que ofrecían para crear experiencias auténticas a los turistas. Para el recorrido de estos tours acudí a las principales agencias de la ciudad de San Cristóbal, y participé en 14 trayectos que organizaban la visita a los municipios de San Juan Chamula y Zinacantán. Las agencias de viajes tienen conexiones con los hoteles y recogen a los turistas por las mañanas. Algunos guías trabajaban para varias agencias a la vez por lo que, en algunos casos, repetía el viaje con los mismos y observé cómo habían memorizado la misma información y jugaban con las mismas bromas.

Las entrevistas a turistas nacionales y extranjeros se realizaron durante los tours en la ciudad y hacia las comunidades indígenas. Fueron conversaciones informales que aportaron información valiosa sobre cómo los turistas que viajan en tours organizados interpretan el entorno étnico. Una gran mayoría de estos turistas procedían de otros estados de la República Mexicana y tenían ideas preconcebidas sobre los indígenas de Chiapas; el estado más al sur de México que ha representado un entorno aislado, y a la vez salvaje, dentro del contexto multicultural de Chiapas; un estado también donde los indígenas revolucionarios del EZLN (Ejército Zapatista de Liberación Nacional) hicieron temblar el poder político de México en el año 1994. Una gran mayoría de turistas extranjeros provenían de Estados Unidos, Argentina, Chile y Europa (mayoritariamente de España, Francia e Italia). Muchos de ellos habían programado los viajes desde los lugares de origen y sabían lo que iban a recorrer y observar. Otros, sin embargo, organizaban los trayectos desde la capital de San Cristóbal y alternaban los tours étnicos con rutas a centros arqueológicos y naturales. En sus recorridos turísticos he escuchado sus conversaciones y opiniones sobre lo que observan, cómo lo interpretan y cómo hablan de la disyuntiva entre la tradición indígena y la modernidad del turista, pero también sobre lo que es auténtico o se mercantiliza para los ojos del turista.

La comparación entre las visitas oficiales y los tours privados a otros municipios indígenas me ayudaron a profundizar en los discursos esencialistas que esconden la situación y posición de los indígenas de Los Altos. Las visitas a Tenejapa, Chenalhó y San Andrés Larráinzar se hicieron acompañada con una guía que había contratada personalmente desde la Asociación Cultural Na Bolom. Dedicamos tres días a recorrer otros municipios de la región que no son tan visitados y me ofreció información relevante y de primera mano sobre la situación social de la población indígena. El viaje lo efectuamos en combis y transportes regionales, a menudo durante varias horas para llegar al destino. Con ella acudí también a visitar San Juan Chamula y Zinacantán, revelando datos que las agencias oficiales escondían. El recorrido de

\footnotetext{
${ }^{3}$ Los caracoles zapatistas se formaron en el año 2003 como comunidades autónomas paralelas a las constitucionales. Actualmente el territorio zapatista se divide en cinco regiones y cada una tiene un caracol como centro de gobierno autónomo y sede de las Juntas del buen Gobierno (JBG). Allí nombran sus propias autoridades y servidores públicos y construyen sus propios sistemas de educación, salud pública y administración de justicia.
} 
Tenejapa se efectuó por la iglesia y calles de alrededor y no apareció ningún turista. Acudimos a una cooperativa en la entrada de la cabecera con una gran cantidad de prendas textiles de alta calidad, desgastadas y amontonadas unas encima de las otras, sin salida comercial en el municipio. La visita a San Andrés Larráinzar se efectuó en un día entre semana para visitar la cabecera y dos cooperativas indígenas; allí venden textiles y objetos relacionados con el zapatismo sin interés actual por un tipo de turista que busca los escenarios exóticos de tradición indígena. Por último, la visita al caracol zapatista de Oventik se realizó también con un guía privado que trabajaba para una agencia de viajes secundaria y ofrecía tours personalizados y acompañados con su propio vehículo. Visitamos todo el centro y hablamos con sus integrantes; entramos también en las tiendas zapatistas con venta escasa por la poca presencia de visitantes.

Asimismo, se privilegió la observación de los lugares donde sucede la interacción turista/anfitrión en las calles, especialmente en los andadores turísticos y en los mercados artesanales de la ciudad y alrededores, así como en las iglesias, cementerios, casas particulares y otros lugares de exhibición turística en los municipios indígenas. Aquí, en estos espacios de interacción, donde unos se exhiben y otros se divierten a través del consumo cultural, mis preguntas giraban en torno a la posibilidad que tienen los anfitriones protagonistas de cambiar las reglas de presentación y cómo pueden manipular para su propio beneficio los imaginarios que corren sobre ellos. Por último, la observación en otros espacios de consumo como tiendas, museos y centros de ocio y restauración que adornan sus locales con objetos indígenas, proporcionaron información esencial para entender los lugares específicos donde se condensan los imaginarios asociados a la población indígena, ajena a su vida real y con una participación marginal en los negocios turísticos.

Me centro en Los Altos por ser una de las zonas con una población indígena mayoritaria y donde se mantienen relaciones de dominio bajo el poder económico y político de los mestizos (ladinos) aposentados en la capital de San Cristóbal de Las Casas $^{4}$. Se trata de una región montañosa y fría que hace difícil el cultivo en sus tierras y los recursos naturales siempre han sido escasos. La población campesina indígena que vive en los alrededores de la capital ha tenido que recurrir al trabajo asalariado, al comercio informal de alimentos o artesanías y a la migración forzada para su subsistencia. Al contrario, San Cristóbal de Las Casas es una de las principales ciudades criolla y mestiza desde la época colonial y allí se reproducen las antiguas relaciones de poder históricamente conformadas y muy marcadas por las diferencias étnicas entre ladinos e indígenas. Hoy día se ha convertido en un centro turístico estratégico por ser lugar de llegada y partida de los números tours turísticos que recorren la ruta del Mundo Maya $^{5}$ del sureste mexicano. Si bien el dominio del escenario étnico en

\footnotetext{
${ }^{4}$ Según el Censo de Población y Vivienda del año 2010, 15 de los 17 municipios que conforman la región Los Altos tienen una mayoría de población que habla alguna lengua indígena $(75,2 \%)$ especialmente tsotsiles (62,3\%) y tseltales (37,2\%), así como otros grupos minoritarios como zoques, tojolabales y choles. La población total de hablantes de alguna lengua indígena se eleva a 408958 frente a 133354 de no hablantes (INEGI 2010).

${ }^{5}$ El proyecto turístico del Mundo Maya empezó a desarrollarse por la Secretaría de Turismo, SECTUR (<http://www.gob.mx/sectur/>, fecha de acceso: 15 ene. 2018) en 1989 junto con los países vecinos de Belice, El Salvador, Guatemala y Honduras para promocionar la visita de zo-
} 
la ciudad se halla en manos de los mestizos que se han convertido en empresarios y se han sumado a las iniciativas de extranjeros con grandes inversiones en servicios turísticos, el propósito de este trabajo es presentar otros procesos de la actividad turística con protagonismo indígena que pueden, incluso, trastocar las relaciones de dominación histórica de la región.

\section{LOS TOURS ÉTNICOS EN LA SOCIEDAD GLOBAL}

En la actividad turística pensar en términos de autenticidad resulta cada día más difícil. Por un lado, la autenticidad es un elemento esencial a la hora de valorar el viaje, pero en la mayoría de los casos hay un escenario prefabricado en base a estereotipos y esencialidades turísticas. En los viajes calificados como étnicos los turistas buscan acercarse a lo que ellos consideran como la auténtica vida indígena y experimentan con esa idea y esos imaginarios. A la vez, cargan a sus espaldas una serie de signos codificados necesarios para visibilizar lo exótico y el viaje casi termina por ser una excusa para verificar sus estereotipos visuales (Wang 1999; Urry 2002; MacCannell 2003). Muchos imaginarios son construidos por la fábrica visual que crea un mundo de apariencias sobre la cultura de los Otros, imaginados como diferentes, extraños o exóticos, en contraposición a la cultura occidental/global propia del turista. Para un fácil acercamiento a ese Otro imaginado, la fábrica del turismo pone al abasto este mundo recreado para el turista; un imaginario de seducción y fantasía, como afirma Salazar (2012: 865), en el que la cultura (en su expresión de objetos, personas, rituales y otras prácticas) se convierte en un objeto de consumo global y las ciudades de destino, o al menos las que se convierten en lugares estratégicos para la salida de los tours turísticos, se transforman en lugares de ocio con todos los servicios turísticos de restauración, hospedaje y diversión. Allí, en los espacios de interacción, se configuran las fantasías e imaginarios turísticos sobre la alteridad y se manifiestan en las prácticas sociales del turismo internacional (Salazar 2012). La diferencia cultural se convierte en esencial para crear una oposición binaria inexistente; la cultura del Otro se proyecta como diferente, se acentúan sus esencias culturales, se mitifican sus pasados y se idealiza su presente. En cierta forma, la visión exótica y mítica niega un estar aquí presente para presentar un estar allá diferente y reproduce una visión necolonialista de ese Otro (Van den Berghe 1995: 571) que, inmerso en un mundo de desigualdades, es exhibido como ausente del mercado capitalista global.

Esta mirada constructiva del turista se combina con la necesidad de experimentar con esa otredad y autentificar el viaje a través de la actividad sensorial (Graburn 1992; Wang 1999). De hecho, el turismo étnico juega con ciertas ventajas por su manera peculiar de experimentar con la autenticidad, posibilita entrar a un escenario trasero de difícil acceso (que en muchos casos es frontal), requiere la ayuda de expertos o guías sin los cuales no hubiera sido posible la entrada, permite la visualización de lo exótico en vivo y con ello la observación/participación de sus elementos más visi-

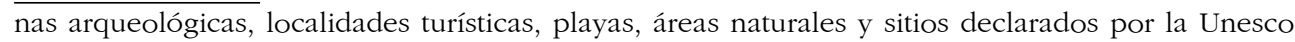
como Patrimonio de la Humanidad. En México la ruta maya incluye los estados de Campeche, Chiapas, Quintana Roo, Tabasco y Yucatán. 
bles. En cierta forma, como señala Urry (2002) se trataría de una perspectiva sensorial de un cuerpo espectador (turista) que entra en movimiento para experimentar sensaciones y comulgar con un signo de la cultura del anfitrión a través de su corporalidad. Wang afirma incluso que esta necesidad del turista de experimentar, más que observar como un espectador ante un espacio frontal, es lo que le confiere la autenticidad buscada: la de sobrepasar el marco de lo ordinario, establecido y controlado por roles normas sociales para entrar y sentir un mundo extraordinario de sensaciones liberadas. El tour étnico permite salir de la rutina diaria y experimentar con la fantasía del exotismo en un mundo donde el espectáculo y la diversión cobran cada día una mayor relevancia (Graburn 1992; Cohen 2005).

El tour étnico no solo sirve para deleite del turismo, es también una presentación social de ese Otro cuyas modalidades de presentación oscilan entre acoplarse a los estereotipos creados y cumplir con las expectativas de los visitantes o crear espacios propios que le permitan capturar cierto protagonismo. Ambas estrategias pueden implicar, en un primer término, modalidades diferentes de presentación y también de inserción en la industria turística. Basta observar las creaciones que hace la industria del turismo de esos Otros que a veces son difíciles de cumplir frente a la realidad pobre y marginal en la que están inmersos. Este sería el caso específico de la población indígena de Los Altos, que trabaja mayoritariamente en la actividad agrícola y el comercio ambulante y tiene serias dificultades para sacar recursos de otras fuentes económicas (Figura 2). Con la llegada del turismo a la zona se enfrenta a la necesidad de presentarse como un objeto distanciado y alejado de la realidad y, a la vez,

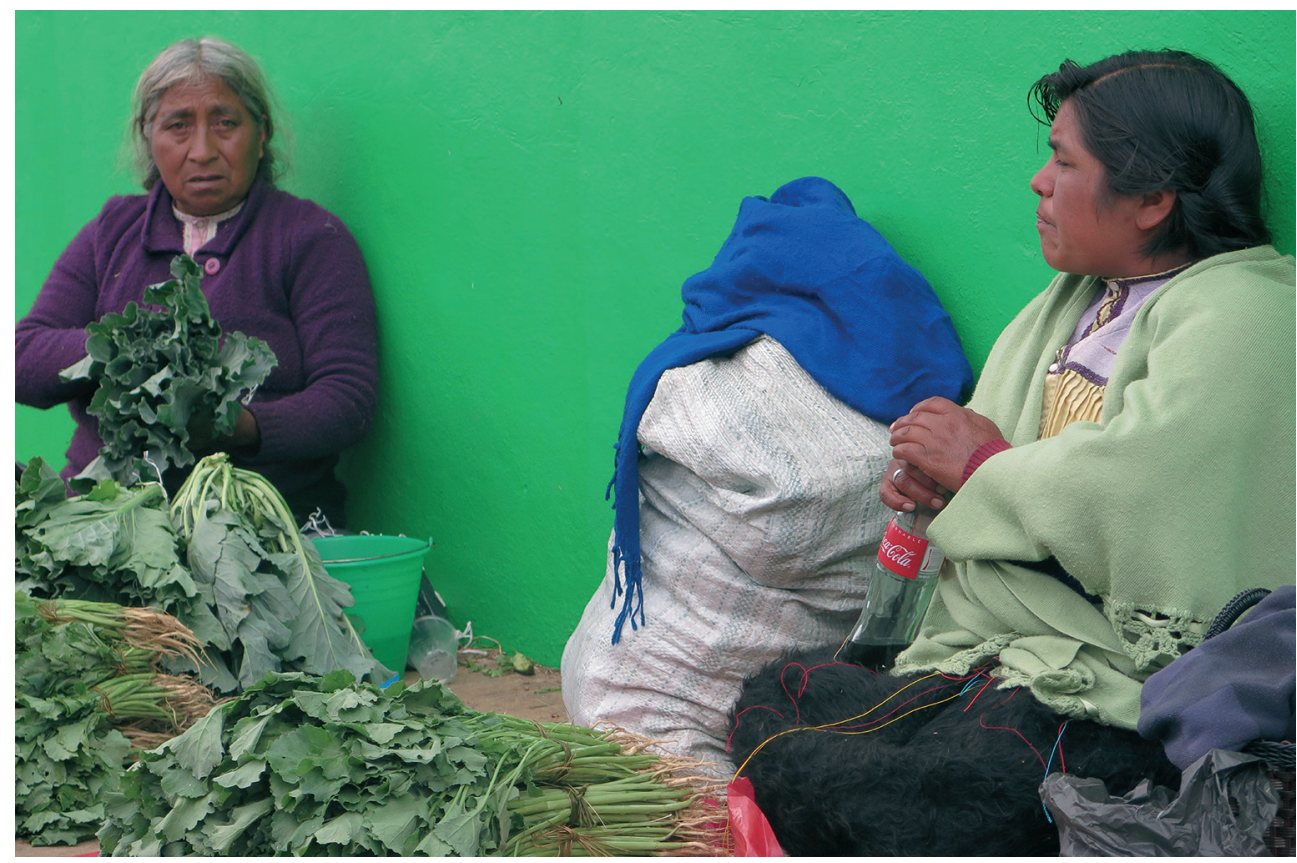

Figura 2.- Vendedoras de alimentos en el mercado de San Juan Chamula. Foto: Eugenia Bayona 
intentar sacar provecho y sobrevivir del negocio. Los indígenas que no cumplen los requisitos de la industria pueden ser abiertamente marginados o, al contrario, convertirse de la noche al día en el prototipo de presentación adecuada.

En Los Altos, la fábrica del turismo ha creado y utilizado signos codificados sobre el exotismo indígena, idealizando su cultura como reducto de un pasado maya que incorpora tanto sacralidad y espiritualidad como tradición prehispánica. También se representa a esta población en sincronía con la naturaleza y el medio ambiente y, en consecuencia, más pura y sana que la sociedad contaminante actual. En esta representación institucional siempre hay el intento de esencializar al Otro y no demostrar abiertamente su dependencia marginal con la sociedad global. Una estrategia de ocultamiento puede hacerse mediante la presentación de lo exótico como espectáculo. Sería el caso de exhibir el ámbito histórico como un gran teatro, presentar sus ruinas iluminadas y organizar espectáculos y eventos festivos. Otra estrategia sería el contacto con partes de su cultural y convertir sus aldeas y casas en pequeños parques temáticos con rutas planificadas para exhibir lo más esencial y característico. No obstante, pensar en términos de aislamiento resulta complicado para un negocio que vive de la exhibición de la realidad. No siempre se puede ocultar la pobreza de la gente ni las condiciones precarias de un espacio marginal. Tampoco se pueden obviar los contactos que se realizan con el Otro y las consecuencias que estos contactos pueden provocar.

La actividad turística constituye un foco central de atención en un ámbito pobre y marginal porque se convierte en un ámbito, quizás el único, que permite extraer recursos y también capturar espacios relevantes no exentos de negociaciones y conflictos. El turismo no es solo una estrategia económica que permite salir de la pobreza, es también un lugar de presentación de esta etnicidad comercializada como la exaltación de una diferenciación cultural bajo parámetros globales. En estos nuevos contextos creados por y para el turismo pueden presentarse nuevas formas de etnicidad mercantilizada en la que se potencia la exhibición de referentes culturales para establecer distinciones y marcar diversas fronteras físicas, sociales y políticas (Cohen 1988; Comaroff y Comaroff 2011). En los espacios escogidos resulta posible la modificación de la etnicidad, entendida como un proceso inmerso en relaciones de poder entre una mayoría legitimada y una minoría históricamente marginada. Así, como veremos más adelante, los indígenas de Los Altos no crean imaginarios turísticos, sino que más bien los utilizan para capturar espacios estratégicos y con ello ganar espacios económicos, políticos y sociales. Lo que importa es la capacidad para construir diferencia, aunque para ello tengan que acoplarse al esencialismo cultural turístico. Los casos que vamos a estudiar presentan a sujetos marginales que sobreviven dentro del negocio turístico de la etnicidad, pero que desarrollan estrategias para presentarse y demuestran un estar allí exhibiendo una diversidad ahora valorada y consumida desde coordinadas globales.

\section{LA PROMOCIÓN DE LOS TOURS MAYAS}

El turismo en el estado de Chiapas atrae cada día a un mayor número de visitantes. Según La Secretaría de Turismo del Gobierno del Estado de Chiapas, en el año 
2016 arribaron al estado 5616972 turistas entre nacionales y extranjeros y la propia ciudad de San Cristóbal recibió 838000 turistas en el año 2015 que se hospedaron en hoteles de la ciudad (INEGI 2016). Los Altos ha sido descubierta recientemente por la industria del turismo; sus antecedentes se remontan solo a la década de 1940 cuando antropólogos ${ }^{6}$, exploradores y aventureros llegaron para observar y estudiar la cultura indígena. En la década de 1970 les siguieron mochileros y hippies que llegaban desde Estados Unidos en su camino hacia la Antigua Guatemala y hacían un alto en el camino en San Cristóbal. No es hasta el año 1994 que se convirtió en un centro de interés internacional a raíz del levantamiento del EZLN y se transformó en un lugar simbólico de lucha revolucionario y base central para la actuación de numerosas ONG, en defensa de los pueblos indígenas. La llegada de turistas se incrementó a partir de años posteriores y apareció entonces un tipo de turista politizado atraído por el movimiento indígena (Coronado 2008). Pero el impulso turístico se fortaleció a partir de la década de 2000, cuando las inversiones estatales y privadas volvieron a tomar las riendas en San Cristóbal y se estableció una infraestructura necesaria para acoger a visitantes de clase media o adinerada. Hoy en día es considerada la principal ciudad turística de Chiapas y paso obligado para turistas nacionales y extranjeros que organizan sus viajes y planifican las rutas desde sus orígenes (Mapas 1 y 2).

La escenografía de la ciudad ha sido modificada para el turismo y transformada para el consumo; grandes casas coloniales se han convertido en hoteles, algunos de lujo, o en restaurantes, bares, cafés y tiendas de artesanías ${ }^{7}$. Las calles principales son peatonales y reciben el nombre de andadores turísticos y han aparecido museos de productos originarios de Chiapas —ámbar, jade y chocolate-, o sobre temáticas indígenas — trajes, otros objetos o medicina maya-. También se muestra la Casa-museo $\mathrm{Na}$ Bolom, antigua propiedad de la pareja Franz y Trudy Blom ${ }^{8}$, en el que se recorren las antiguas habitaciones de su hogar y se informa sobre el amplio trabajo etnográfico y arqueológico que la pareja realizó con los indígenas lacandones en la región Selva, al norte de Chiapas. Hay lugares olvidados, como la periferia de la ciu-

\footnotetext{
${ }^{6}$ Desde las décadas de 1940-1960, la región de Los Altos se convirtió en un observatorio privilegiado para estudiar la supervivencia de las sociedades prehispánicas mayas y aparecieron investigadores de la Universidad de Chicago, Harvard y de la Escuela Nacional de Antropología e Historia de México (ENAH) (Viqueira 2002).

${ }^{7}$ En el año 2016 se contabilizaron 204 hoteles de diferentes categorías registrados oficialmente, aunque existen muchos otros, como casas de albergue y posadas, que no se hallan regulados y la cifra bien se podría duplicar. Aun así, según las cifras oficiales se sitúa en primer lugar con respecto a la oferta hotelera y en relación al resto de ciudades importantes de Chiapas (la capital de estado Tuxtla Gutiérrez, Tapachula, Palenque, Comitán y Tonalá). Por su parte, los restaurantes ascienden a 190 mientras que las agencias de viajes registradas suman 52 (INEGI 2016).

${ }^{8}$ La pareja estableció su residencia en San Cristóbal en el año 1943 y dedicó su estancia a la investigación y documentación de los indígenas de la Selva Lacandona. En el año 1951, formaron la Asociación Cultural Na Bolom en su residencia particular. Actualmente, la Casa-Museo Na Bolom A.C. (Casa del Jaguar en tsotsil) es un hotel-museo que combina el negocio del turismo con las actividades que promueve la asociación civil para proteger y conservar el medio ambiente de la Selva Lacandona y difundir el patrimonio cultural de los grupos indígenas de Chiapas, especialmente los lacandones.
} 


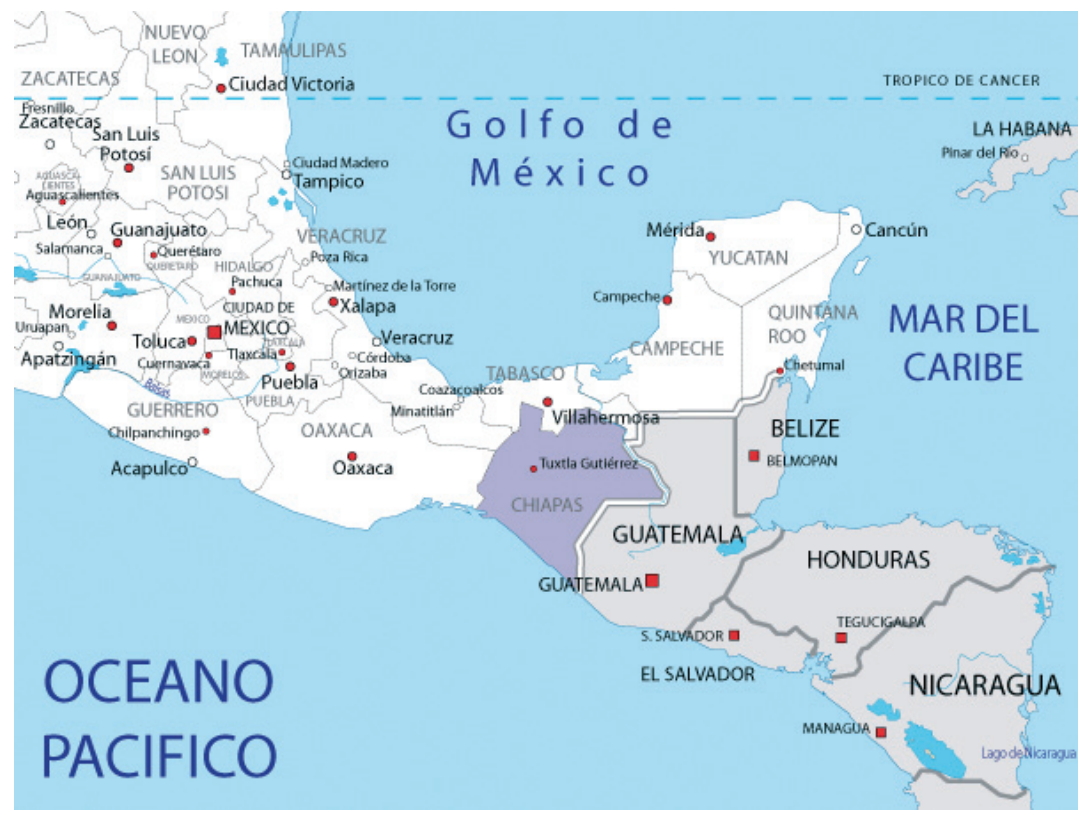

MAPA 1.-Mapa del estado de Chiapas.

Fuente: <http://www.map-of-mexico.co.uk/espanola/mapa-de-chiapas.htm>

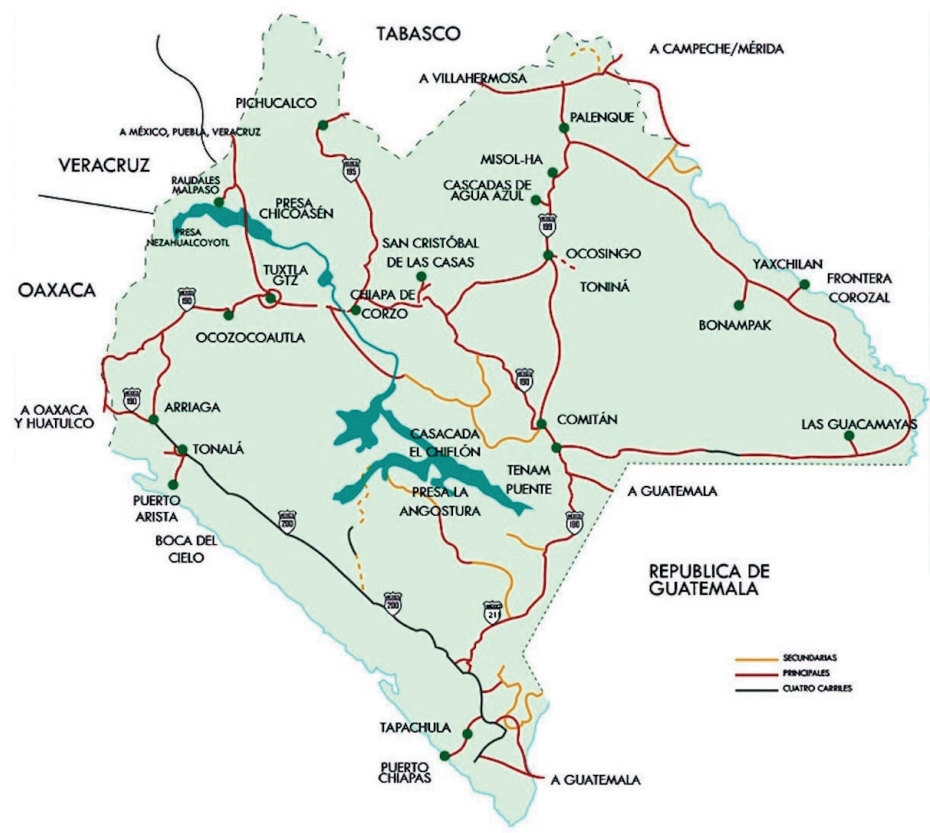

MAPA 2.-Mapa turístico del estado de Chiapas.

Fuente: <https://www.viajachiapas.com/mapas-y-recorridos/> 
dad donde los indígenas viven diariamente una realidad cruda y marginal ${ }^{9}$, Las unidades administrativas, municipales y gubernamentales han sido trasladadas a las afueras para no estropear la escenificación de una ciudad que por las noches ilumina todas sus plazas, iglesias y andadores. La música en vivo en diferentes lugares se combina con los espectáculos callejeros y ferias de exhibición según temporadas. Por su parte, la decoración de hoteles y restaurantes permiten ver esta simbiosis del mundo indígena y colonial efectuada para el turismo; hoteles con réplicas de algunos edificios y detalles coloniales junto a ornamentos y textiles indígenas.

En el centro de San Cristóbal se han instalado las principales agencias que ofrecen tours a toda clase de destinos naturales, arqueológicos y culturales en diversos puntos del estado de Chiapas. Para conseguir un mayor número de visitantes, se sitúan en lugares estratégicos y tienen conexiones con los mejores hoteles de la ciudad. Además, cada día se idean nuevas rutas para que la atracción turística no decaiga. El comercio ha tenido también un impulso importante con la ampliación de mercados artesanales como el tianguis de Santo Domingo o el Mercado de Dulces y Artesanías de Chiapas y la apertura de tiendas propiedad de mestizos y extranjeros que ofrecen artesanía mexicana e indígena acoplada al turista étnico. Las cooperativas y asociaciones indígenas también se han incorporado al negocio de la venta y ofrecen textiles procedentes de municipios como Aldama, Tenejapa, San Andrés Larráinzar, Pantheló, Chenalhó, Chamula, Zinacantán, Aguacatenango y Oxchuc entre otros (Ramos 2010).

El incremento del turismo también ha derivado en intervenciones nacionales y estatales para planificar la estancia del visitante como una oportunidad para el desarrollo económico de la zona. Especialmente la Secretaría de Turismo ha promocionado la zona con campañas publicitarias en diversos medios de comunicación con base en dos polos importantes de atracción: la ciudad colonial de San Cristóbal de Las Casas y los municipios indígenas circundantes a la ciudad. La población indígena se ha convertido en el foco principal de atracción y se promocionan tours para observar de cerca sus tradiciones culturales, promoviendo incluso la participación del turista en la vida sagrada y cotidiana del indígena. Por el contrario, una gran mayoría de indígenas sobrevive de las actividades autosuficientes del campo y de la venta de excedentes en los mercados centrales y, prácticamente, es la mano de obra formal e informal que trabaja mal pagada en el negocio del turismo.

El desarrollo del turismo desde Los Altos hacia otras regiones de Chiapas ha ido ampliando su oferta con destinos cada día más alejados y diversos. Las bellezas naturales se han multiplicado, a pesar de que el acceso a algunas de ellas todavía es deficiente y requiere horas de autobús para llegar al destino. Es el caso por ejemplo de los tours que incorporan visitas a ruinas arqueológicas de Palenque, Bonampak, Toniná o Yaxchilán, combinadas con un paseo por lagos, selvas y montañas. Una nueva ruta ofrece ahora la visita guiada por las fincas cafetaleras en la región Soconusco, o subir al volcán Tacaná en el sureste de Chiapas. Los paseos a caballo por playas, el descenso de ríos, el buceo, la visita a cuevas y las rutas ecológicas se ofre-

\footnotetext{
${ }^{9}$ La mayoría de esta población indígena que vive en la periferia llegó en la década de 1970 a causa de las expulsiones en sus municipios de origen por su conversión al protestantismo. La ciudad se ha indianizado por el crecimiento de la población indígena: un $37 \%$ más en el año 2010 (INEGI 2010). Una gran parte de esta población indígena urbana trabaja en hostelería, restauración, transporte y comercio relacionados con la actividad turística.
} 
cen como viajes de aventura accesibles para todos los visitantes. Las nuevas modalidades de turismo han resultado ser exitosas y se basan en la enorme riqueza natural e histórica del estado que tiene todavía enormes zonas inexploradas. Estaríamos hablando de ese misterioso mundo maya que ha sobrevivido, en parte, por el aislamiento marginal de sus pobladores; una naturaleza virgen y a la vez un entorno privilegiado para conservar el mundo prehispánico.

Para el caso específico de Los Altos, las rutas permanecen bajo el mismo esquema que fueron ideadas en su principio con solo algunas pequeñas variaciones: la ruta colonial en San Cristóbal ha incorporado la visita a nuevos museos de jade, ámbar, chocolate, café, medicina, trajes y objetos indígenas; la ruta a los Pueblos Indios, Pueblos Indígenas o Pueblos Mayas (tal como se promociona en las agencias) se mantiene con la visita a dos municipios cercanos a la ciudad, San Juan Chamula y Zinacantán, con nuevos recorrido por mercados, casas particulares y talleres de producción. Se estima que alrededor de 400 o 500 turistas diariamente visitan estos municipios en la temporada alta de Semana Santa, los meses de verano y las dos últimas semanas de diciembre en Navidad. Los tours a municipios indígenas son relativamente escasos si consideramos que la región tiene una mayoría de población que habla alguna lengua indígena. Los discursos oficiales hablan del poco interés que existe en exhibir centros indígenas donde no hay nada que enseñar. Léase en este discurso una exhibición de pobreza y marginación social que no cumple con los estereotipos étnicos de escenificación requeridos. Sin embargo, también deben ser escuchados otros discursos tras estos esquemas institucionales; la negociación necesaria con las autoridades indígenas que permiten o prohíben el acceso turístico a sus municipios.

La entrada de los tours turísticos a San Juan Chamula y Zinacantán se ha hecho con ciertas reglas y prohibiciones. Si bien es cierto que la visita a la cabecera de cada municipio es abiertamente permitida y cualquier turista por su cuenta puede llegar con el trasporte público o con taxis compartidos, lo que realmente se prohíbe es la entrada de autobuses oficiales de agencias de viajes y la intromisión de tours que pasean abiertamente por sus calles. Como consecuencia, el guía debe pagar una entrada para que se permita la entrada del autobús y realizar una ruta acordada por las autoridades indígenas. Independientemente de la agencia contratada, el tour a los Pueblos Indígenas tiene una duración de media mañana, y en pocas horas el turista va a experimentar con múltiples imaginarios indígenas: el indígena espiritual cercano a una naturaleza sagrada, el ecologista y protector del medio ambiente, el indígena ritual que combina historia y tradición o la artesana que conserva su tradición en las artes manuales. Esta combinación ha sido posible por narrativas ajenas, pero también por discursos incorporados como propios en la sociedad indígena y tienen efectos diferentes según quienes los utilicen. Las agencias pueden utilizan visiones atemporales y esencialistas, pero deben acoplarse a las rutas que permiten los indígenas. Por su parte, los indígenas pueden defender la preservación de una cultura que despareció hace siglos tras el dominio colonial, y a la vez, están ganado espacios de negociación en un contexto dominado históricamente por la sociedad mestiza. Es cierto que el turismo implica el convertirse en un objeto de consumo que nada tiene que ver con la realidad presente en la que viven y también es cierto que, en muchos casos, no intervienen en la creación de los imaginarios que los envuelven. Por otro lado, es una actividad que asegura la reproducción económica y social de muchas familias indígenas y permite soñar con un mejor futuro para sus hijos. 


\section{EL TOUR DE LAS VENDEDORAS INDÍGENAS EN SAN CRISTÓBAL}

San Cristóbal de Las Casas es promovida como un centro colonial que conserva un patrimonio arquitectónico inigualable, con cerca de 520 monumentos históricos anteriores al siglo XX. Desde 1989 el centro histórico ha sido declarado Zona Monumental por el Instituto Nacional de Antropología e Historia (INAH), Pueblo Mágico en el año 2003 por la Secretaría de Turismo y, recientemente, ha recibido el galardón de ser «el más mágico de los Pueblos Mágicos de México". La ciudad colonial es el eslogan de las élites mestizas que viven y gobiernan en la ciudad y que promocionan el pasado de conquista como forma de legitimar su poder actual, olvidando el papel que tuvieron los indígenas en la construcción de la ciudad y el que tienen hoy en día en la exhibición turística (Paris Pombo 2000; Hovstoff 2004; Robledo 2009). La propia estructura de la ciudad demuestra la desigualdad social; mientras en el centro viven las grandes familias ladinas, se reconstruyen casas coloniales y se abren hoteles, restaurantes, tiendas o museos, en la periferia y bordeando la ciudad se asientan colonias marginales que albergan a la cada día más numerosa población indígena. Los inmigrantes indígenas ya representan más de la tercera parte de la población de la ciudad y a ella se traslada también cada día una población indígena flotante para trabajar en la construcción, en los servicios de hoteles y restaurantes y principalmente como vendedores ambulantes de alimentos y souvenirs turísticos (Figura 3).

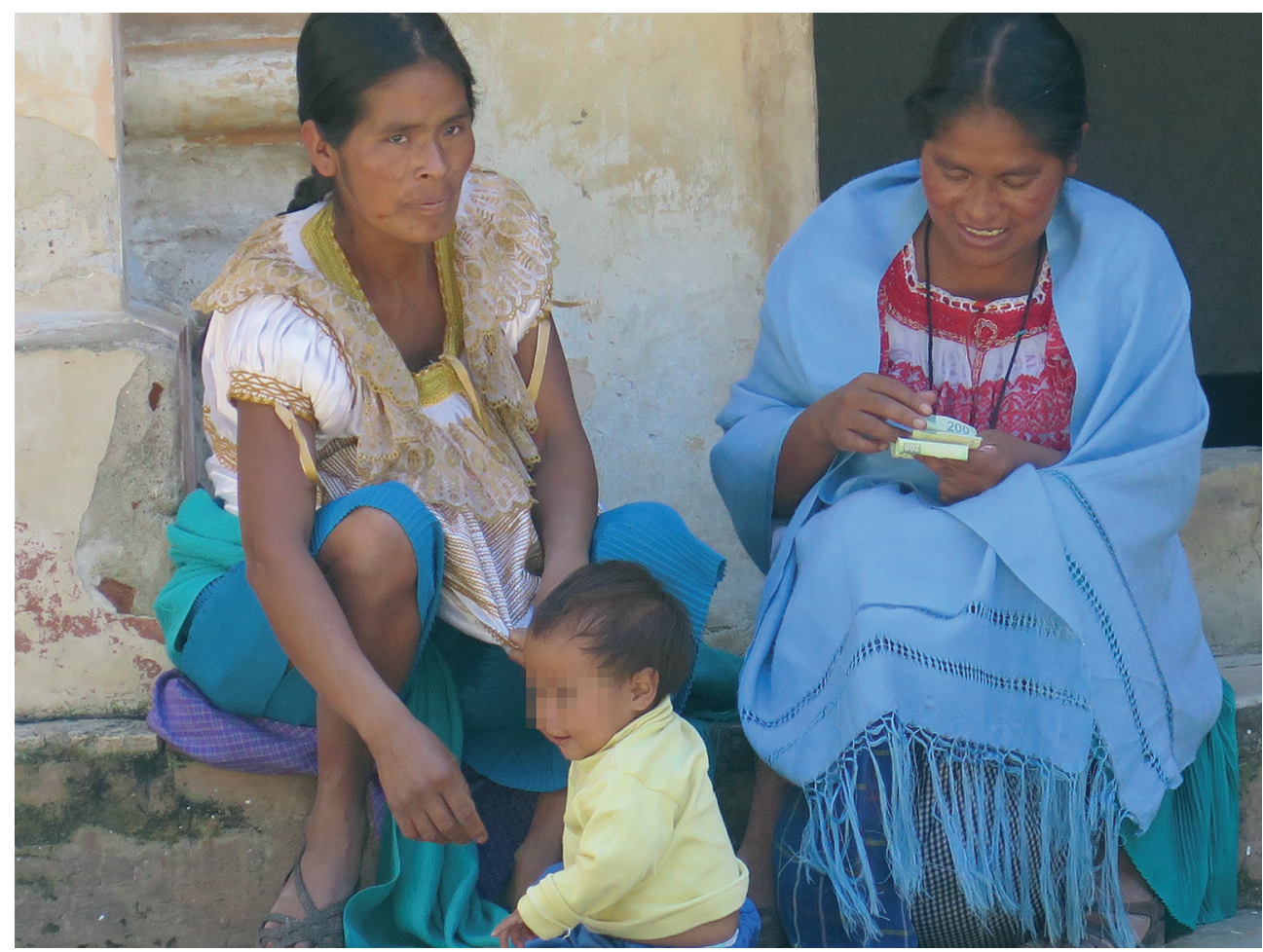

Figura 3.--Mujeres indígenas en San Cristóbal de Las Casas. Foto: Eugenia Bayona 
El asentamiento de indígenas en la ciudad se asocia con las intensas migraciones acontecidas desde la década de 1970 por la pobreza insostenible ante la economía agraria de subsistencia y por las primeras expulsiones indígenas por motivos políticos y religiosos. Las autoridades políticas del municipio de San Juan Chamula en su mayoría, y de otros municipios de la región como Zinacantán, Chenalhó, Tenejapa o Mitontic entre otros, obligaron a miles de indígenas protestantes a abandonar sus comunidades y buscar refugio en la ciudad (Morquecho 1992; Cantón Delgado 1997; Robledo 1997). Su llegada a San Cristóbal significó una primera búsqueda de espacios de residencia y trabajos informales que les permitieran asentarse y sobrevivir en un espacio ajeno. Muchos de los que fueron expulsados vieron en esta migración urbana un movimiento transitorio, pero con el paso de los años, y ante la imposibilidad de volver a sus hogares, fueron desarrollando formas de organización comunes. Se instalaron en el periférico norte y formaron colonias en terrenos situados en las afueras de la ciudad que no contaban con los servicios públicos mínimos como drenaje, agua entubada o electricidad. Allí formaron espacios comunitarios de apoyo, fueron construyendo una identidad panindígena que unía a indígenas de diferentes religiones y de procedencia comunitaria, y formaron diferentes afiliaciones políticas, sociales, laborales o religiosas fuertemente corporativas para defender su presencia urbana.

Desde el principio, los indígenas urbanos desarrollaron algunas actividades relacionadas con la venta de artesanías y productos comestibles como oportunidades más recurrentes. Algunas mujeres empezaron por vender souvenirs por las calles procedentes de las tiendas de artesanías propiedad de ladinos. Con el paso del tiempo, fueron fortaleciendo su presencia como vendedoras en puestos fijos y conquistaron el principal mercado de artesanía de la ciudad alrededor del exconvento de Santo Domingo. Este nicho comercial ha perdurado por más de 30 años y es controlado hoy en día por asociaciones de mujeres indígenas, en muchos casos con líderes hombres que exigen cuotas para ejercer la venta. Allí venden toda clase de souvenirs creados para el consumo turístico (faldas, huipiles, rebozos, manteles, tapetes, caminos de mesa, bolsos o cojines entre otros) elaborados por otras mujeres indígenas, procedentes de otros estados de México o importados de países como Guatemala, Honduras, Ecuador o Perú. También ofrecen algunos objetos zapatistas deslocalizados y descontextualizados de su función política y convertidos en souvenirs baratos que algún turista desea llevarse para el recuerdo de lo que fue la revuelta indígena (Figuras 4 y 5). Los puestos de venta se han ido pasando de madres a hijas y con sus ganancias consiguen el sustento necesario para la supervivencia familiar, lo que ha implicado cierto empoderamiento e independencia entre las mujeres casadas. Su participación activa en la economía doméstica les ha permitido negociar espacios de participación y posibilidad de redefinir las relaciones de pareja y familiares. Mientras los hombres trabajan como jardineros o meseros, cargadores y albañiles o se convierten en taxistas y transportistas, muchas mujeres pasan todo el día en sus puestos de venta y han convertido el mercado en un espacio familiar y doméstico. Allí educan a sus hijos, les enseñan a comer, les obligan a hacer sus deberes escolares y les permiten jugar con otros niños. También, aprovechan para enseñarles las técnicas y el negocio de la venta. Por su parte, las jóvenes vendedoras indígenas valoran las oportunidades laborales y educativas que les ofrece el contexto urbano; ganan autonomía económica y social fuera de las normas de género y los roles generacionales impuestas por la costumbre indígena y prefieren, por ejemplo, alargar la soltería o decidir la elección de la pareja (Cruz 2017). 


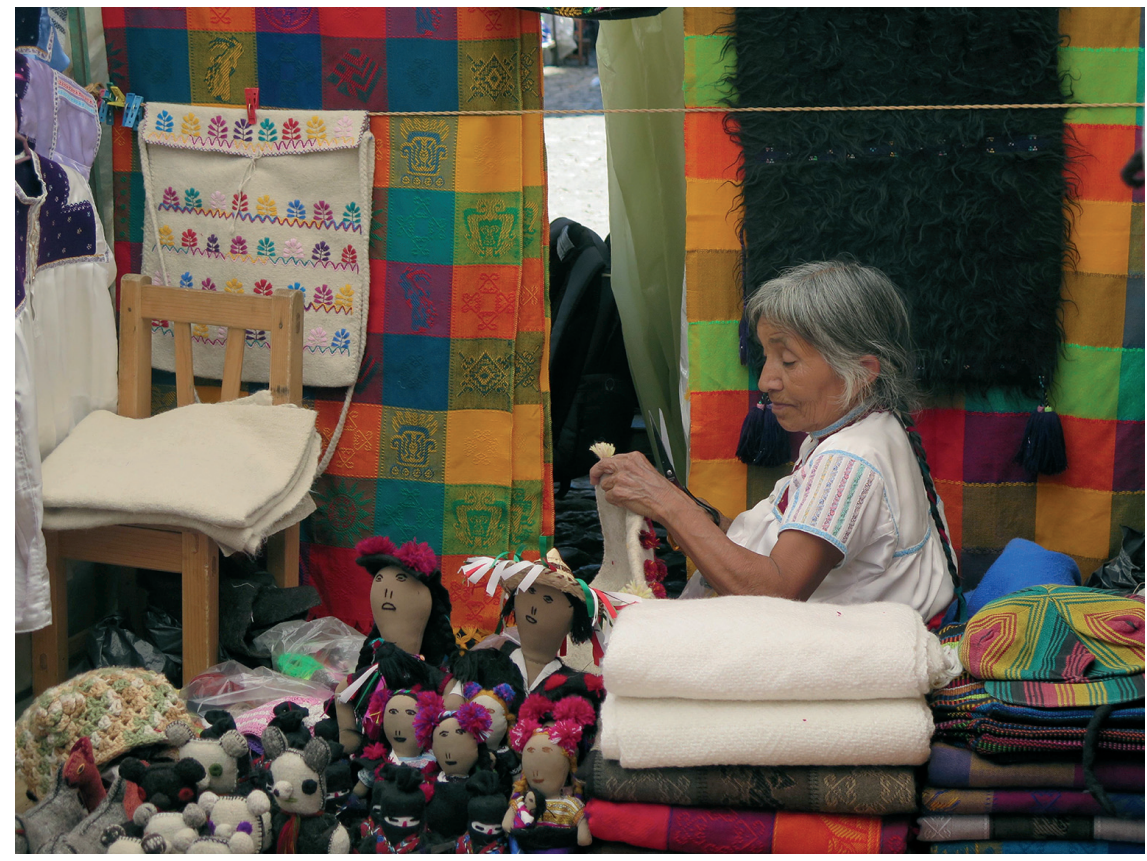

FIguRA 4.- Vendedora indígena en Santo Domingo. Foto: Eugenia Bayona

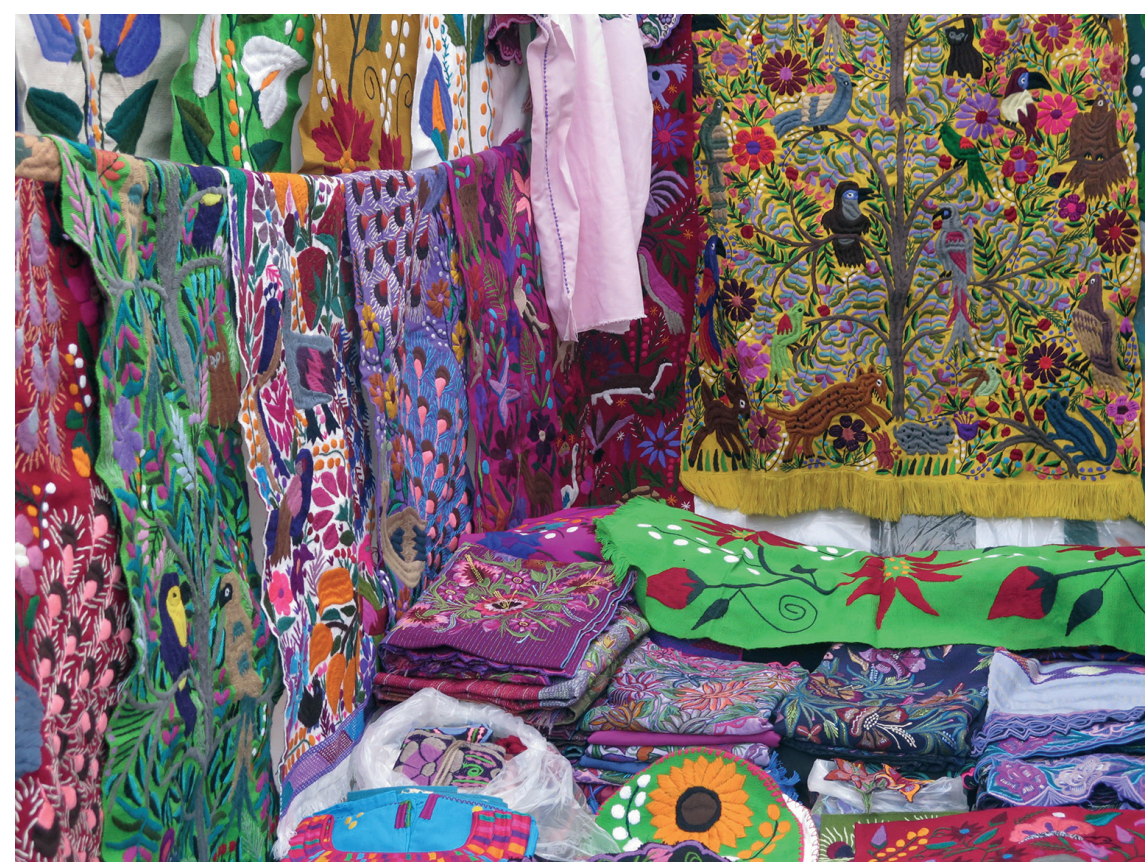

Figura 5.-Souvenirs en Santo Domingo. Foto: Eugenia Bayona 
El atractivo turístico que tiene la artesanía indígena (o la apariencia de la misma) ha permitido a muchas indígenas entrar en el negocio como productoras y vendedoras de textiles y otros objetos. Las tejedoras tienen como centro de distribución la ciudad de San Cristóbal, pero también otras zonas turísticas donde se han aposentado mercados ambulantes. En algunos casos trabajan en colaboración con las propietarias ladinas y extranjeras, como es el caso que documenta Ramos (2004) entre mujeres de Aguacatenango y propietarias mestizas de San Cristóbal, o los casos documentados en mi trabajo de campo de tiendas alternativas que buscan una mayor equidad de beneficio y buscan a mujeres tejedoras en Los Altos para que hagan sus diseños. Otras mujeres se integran a asociaciones y cooperativas indígenas compitiendo con las tiendas de alto standing de algunos nacionales y extranjeros. Algunas han conseguido elevar su estatus, tienen una mayor destreza, exhiben o venden sus tejidos en varias asociaciones y tiendas de renombre, o acuden a ferias nacionales o internacionales. En cambio, una gran mayoría de mujeres producen tejidos de baja calidad para abastecer la amplia mercancía de souvenirs y no consiguen suficientes recursos ni controlan los procesos de distribución y venta; trabajan por pieza bordada, a mano o a máquina, al detalle y por mayor y maquilan para propietarias ladinas, extranjeras o para los comerciantes indígenas que venden por las calles o en los mercados ambulantes

El Mercado de Santo Domingo representa actualmente el mayor espacio comercial turístico de la ciudad. Es ofertado en numerosas guías y ofrecido como un paseo imprescindible dentro del tour colonial. Al estar situado en un lugar con un patrimonio monumental importante (templo de Santo Domingo y templo de La Caridad) los ladinos apelan a que los puestos de venta afean el lugar e invaden un lugar importante del culto católico. El conflicto se ha ido acrecentando con los años y ha sido respaldado por el gobierno de la ciudad que ha dedicado esfuerzos para intentar limpiar la venta callejera en la ciudad, sobre todo desde que se promueve San Cristóbal como Pueblo Mágico y se intenta que el centro sea un espacio limpio y atractivo para el turismo. Las disputas han derivado en intentos de desalojo y enfrentamientos violentos de las autoridades locales sin solucionar el problema básico de reubicación de todas estas vendedoras. Además, los indígenas constituyen una competencia latente para las tiendas de artesanías propiedad de mestizos porque ofrecen productos y souvenirs de peor calidad que pueden ser regateados a precios bajos. Para la población ladina los vendedores trabajan en un espacio ajeno que se ha convertido en caótico e ingobernable y es fuente de constantes conflictos. Como me comentaban algunos comerciantes ladinos: "Son una mafia, mire sus niños todos sucios y sin educación. No, es que ellos están invadiendo todo San Cristóbal, gente indígena, gente que no sabe, gente que ensucia la ciudad" (Vendedora ladina, entrevista personal, 24 jul. 2014); "Es que venden cosas de Guatemala, cosas de otros lugares, ya no venden su artesanía, por eso les echamos" (Vendedor ladino, entrevista personal, 26 jul. 2014).

Los vendedores han fortalecido su presencia con base en las redes que han construido para conseguir puestos y mercancías para la venta. La competencia por los mejores espacios de venta es alta y las organizaciones indígenas han tenido una doble función; ha permitido a los indígenas afiliados negociar a nivel institucional su presencia urbana; ha evitado que otros indígenas que han llegado a vivir a la ciudad se apoderen de los espacios de venta. Muchas otras vendedoras que no han conseguido espacios fijos de venta recorren plazas, parques y principales calles y llevan la 
mercancía a cuestas, o se colocan en la intersección de calles transitadas con puestos a ras del suelo. Algunas consiguen vender en plazas como sitios permitidos durante la temporada turística, pero existen restricciones por parte de las autoridades municipales según los intereses políticos y la temporada turística. Por ejemplo, en temporada alta de verano se autoriza la venta ambulante en La Plaza de la Paz frente a la Catedral y ante el Palacio Municipal, pero en los hoteles o restaurantes se les prohíbe entrar y ejercer la venta; en otros casos, además, se ocultará su procedencia en caso que sean trabajadoras en estos mismos negocios.

En Santo Domingo, las mujeres se han transformado en un objeto turístico que exhibe una identidad asociada a los trajes que llevan y a los objetos que venden. Al igual que las mujeres de la Antigua Guatemala que describió Little (2008), estas vendedoras pueden convertirse en las personas más demandadas en los recorridos turísticos por ser las que conservan una tradición que se idealiza en los folletos turísticos. Además, los espacios conquistados se han convertido también en símbolo inigualable de su presencia en la ciudad y una clara oposición a la discriminación ladina. En palabras de una vendedora: "Ahora la ciudad vive del pueblo indígena, que si la artesanía, que si los mayas. Los ladinos tienen que estar bien rabiosos porque resulta que lo que ellos discriminan es de lo que viven" (Vendedora chamula, entrevista personal, 10 ago. 2014).

Los contactos que realizan los indígenas con los turistas son esporádicos porque la venta requiere brevedad y sacar alguna ganancia. Para los turistas el encontrarse con un mercando indígena al que pueden acceder fácilmente implica poner en acción un ritual de experiencia que incluye también la compra. Es además el espacio donde sus imaginarios étnicos se cumplen porque nadie puede negar que lo que están viendo son auténticos indígenas. Allí regatean, juegan con su rol de turista comprador, hacen fotografías, pasean y se divierten. Los estereotipos son manejados por unos y consumidos por otros y en este espacio conquistado se permite cierta libertad de actuación. Por eso, tanto unos como otros juegan con sus roles y sacan beneficios en un espacio turístico que incorpora muchos significados: para las vendedoras es un espacio económico feminizado que permite a muchas familias indígenas sobrevivir en la ciudad, y a la vez, es un espacio de lucha para la reivindicación e identificación étnica; para los turistas es un lugar donde el contacto es posible y donde adquieren productos que servirán luego para verificar su estancia y demostrar ese contacto real que han hecho con lo étnico y diferente más allá de sus coordenadas cotidianas.

\section{EL TOUR DE LA ESPIRITUALIDAD EN SAN JUAN CHAMULA}

Uno de los mayores atractivos del tour ofertado a San Juan Chamula es la visita al interior de la iglesia, un espacio sagrado con gran condensación de actos y elementos rituales. La ruta a la cabecera del municipio tsotsil ha sido creada como una especie de peregrinaje ritual que refuerza el imaginario del indígena espiritual; se visita el cementerio, se pasea cerca de una casa decorada para el cargo ritual de mayordomo que todo hombre de prestigio debe cumplir como obra social y religiosa a su comunidad, se habla de las montañas sagradas donde acuden los rezadores de cerros para prevenir los males, o se visitan las cruces y altares mayas en la intersección de alguna calle. 
Los mercados ambulantes ofrecen colorido y los atuendos que llevan los hombres y mujeres refuerzan el ambiente exótico. Todo ello no tendría el mismo impacto sin la visita al interior de la iglesia de San Juan Bautista. Allí al turista se le permite ver en primera línea auténticos rituales de curación, con animales, velas y refrescos, que cumplen la función de sanar almas y cuerpos enfermos (Figura 6).

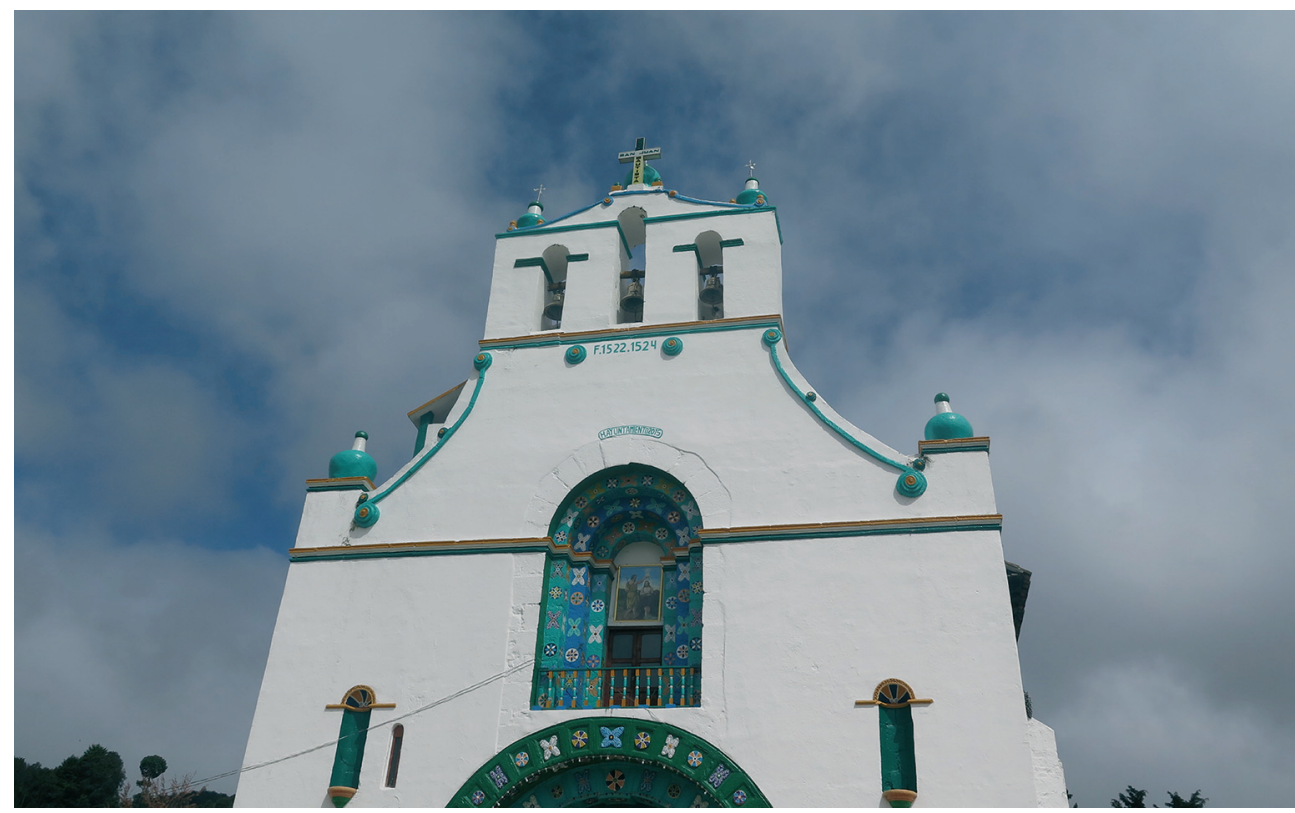

Figura 6.--Iglesia de San Juan Chamula. Foto: Eugenia Bayona

Como otros municipios indígenas, San Juan Chamula se rige por la costumbre o tradición indígena con una serie de oficios políticos y religiosos independientes del sistema político estatal. Para el caso específico de este municipio, el gobierno se halla controlado por una élite que ha consolidado su poder mediante el fortalecimiento de lazos familiares y de amistad con mecanismos de coacción social para subir en la escala política, conquistar ámbitos económicos estratégicos y controlar negocios como el transporte regional y los medios de producción y distribución de productos agrícolas, bebidas y utensilios ceremoniales (Pineda 1995; Rus 1995; Viqueira 1995; Rus y Collier 2002). Actualmente, la gran mayoría de los negocios relacionados con el turismo son manejados por dichas élites, que controlan el transporte de la ciudad hacia los municipios, el pago de la entrada a las cabeceras municipales y/o recintos sagrados e, incluso, el control que poseen de algunas cadenas comerciales de artesanías mercantilizadas como indígenas. Desde hace décadas que una parte importante de la población empobrecida y sin recursos se ha convertido en emigrante y se ha trasladado a vivir a otros estados de la República Mexicana o al vecino país de Estados Unidos, mientras que otras familias han sido expulsadas por no seguir la tradición religiosa y oponerse a la élite en el poder. 
Especialmente los jóvenes chamulas abandonan su municipio de origen para integrarse en redes migratorias internacionales debido a las desigualdades económicas y políticas del municipio. En San Juan Chamula no hay recursos suficientes ni un mercado laboral capaz de absorber toda la mano de obra, ya que en los últimos años se ha producido un aumento significativo de población. Los trabajos como jornaleros agrícolas o asalariados son cada vez más escasos y peor pagados. Las tierras de cultivo se hallan desgastadas por la constante sobrexplotación y la producción agrícola no es suficiente ni asegura la supervivencia familiar. Los jóvenes casados y solteros emprenden un viaje migratorio, a veces sin retorno, y envían remesas para la manutención de la familia en sus orígenes. Las mujeres se han convertido en esenciales y sobrecargan su trabajo doméstico con la producción y venta de alimentos, leña o souvenirs en los centros turísticos (Rus y Rus 2008). Sin embargo, ya sea por los efectos de la migración, por los nuevos ecos de la modernidad y los cambios sustanciales que aparecen por género y edad, las nuevas generaciones exigen mayor participación y una transformación de los modos de vida tradicionales. En este contexto, Neila (2012) habla del discurso de el "nuevo vivir" (ach' kuxlejal) como una forma que tienen los jóvenes de imaginarse y construirse en la modernidad fuera de las normas tradicionales y en oposición a la rígida estratificación indígena. Para los adultos, al contrario, implica recordar el pasado con nostalgia ante los cambios operados por la modernidad inevitable que transforma las raíces y el respeto a los mayores y a la costumbre indígena.

Las transformaciones derivadas de la migración y el turismo han impactado en la economía local y han derivado en una creciente estratificación de clases entre quienes manejan dinero y se enriquecen con las remesas, los préstamos o los negocios del turismo y los que no tienen otra salida más que buscar nuevas oportunidades laborales o acoplarse en segundo plano al ritmo del turismo. El tour de San Juan Chamula se ha convertido en una fuente importante de recursos, y para quienes lo manejan, una forma de expresar poder económico, social y político. El estrato político y una clase adinerada en alza han seleccionado el ámbito religioso como el más representativo para la exhibición turística. Tienen la custodia de la iglesia y exigen el pago monetario para entrar al recinto. No es casual que esta exhibición se manifieste en la vida sagrada, puesto que para los chamulas es la esfera donde se ponen en práctica todas las normas y obligaciones sociales, donde se demuestra la comunalidad y donde se compensa o castiga a los fieles. Además, es el ámbito donde se exhibe la posición social y en la que se manifiesta un prestigio asociado al cargo de mayordomía, el cual implica donaciones económicas cada vez más elevadas ante la disputa por conseguir mayores recursos y ascender a la escala superior. Tampoco es causal que se haya escogido como carta de presentación los rituales que se realizan en el interior de la iglesia y se haya permitido abiertamente la entrada a un público externo. Esto no es novedoso, ya que desde hace décadas las visitas al recinto sagrado han sido una dinámica constante. Lo nuevo ahora es que llegan numerosos grupos de turistas y provocan una masificación dentro del recinto sagrado, especialmente en temporada alta. La iglesia de San Juan Chamula se ha convertido en un espacio de otredad que sirve como presentación social indígena y para rescatar o reinventar un trozo de su cultura (Cohen 1988; MacCannell 2003).

A los turistas se les permite entrar únicamente por las mañanas y hay que pagar una cuota por persona para el acceso. Una vez dentro, deben guardar silencio y res- 
petar las actividades rituales. Tampoco se permite efectuar fotografías o grabar con cámaras, pero lo que hay dentro es motivo de elogio y asombro. Los creyentes acuden a rezar y a pedir sus súplicas y bendiciones a los santos y a curar sus males con la ayuda del i'lol o pulsador, que por medio de rezos y limpias sana a los enfermos. Se trata de un espacio sagrado frecuentado tanto por hombres como por mujeres de todas las edades, aunque la organización interna pertenece a ellos, puesto que los cargos religiosos de mayordomías son tarea masculina y las obras de limpiar y ornamentar la iglesia corresponden a este género. Es, por tanto, un espacio masculinizado que representa un esquema de la sociedad chamula claramente dividida por géneros y jerarquías. Aunque hay algunas mujeres que son pulsadoras, la gran mayoría son hombres que pronostican enfermedades graves, crónicas y agudas: conocen cuáles han sido provocadas por el viento, el rayo, el diablo o el agua, si se han adquirido a través el sueño, por envidia, espanto o mal echado, por alimentos o por conductas socialmente inaceptables. La curación de los enfermos se realiza de rodillas, a ras del suelo, con la ayuda de objetos sagrados como velas encendidas, incienso, gallinas, huevos, bebidas alcohólicas, como el ceremonial posh (licor de caña de azúcar), y otros refrescos que tienen propiedades gaseosas para limpiar el cuerpo (Coca-Cola mayoritariamente y otras como Pepsi, Fanta y Sprite).

Esta práctica ritual es percibida por el turista como símbolo de la autenticidad indígena puesto que las curaciones y los actos rituales se realizan en vivo. El visitante no requiere de grandes conocimientos sobre el lugar ni tampoco realiza contactos profundos y duraderos con los autóctonos; es más bien un observador pasivo que acude a una actuación de performance en un ambiente de humo e incienso y en el que se recitan oraciones indígenas para entrar en trance. Al turista se le anima a respetar el ámbito sagrado y se le deja caminar por el recinto y observar, pero no puede participar en ninguna acción ritual. Quienes se atreven a preguntar algo son amonestados y, en general, el ambiente es de una ritualidad misteriosa y secreta que no permite la intromisión. Ni siquiera los guías pueden implicarse y la gran mayoría aprovecha un espacio en la entrada del recinto para dar algunas explicaciones sobre la ritualidad chamula. En la iglesia se amplía la información, aunque la actuación supera todas las expectativas: "Nunca me esperé que cuando abriera esa puerta viera yo esto" (Turista mexicana, entrevista personal, 30 jul. 2016), "Todo lo que vivimos en tan poco tiempo. Es otro mundo, es otro mundo" (Turista argentino, entrevista personal, 21 jul. 2016), "Dentro de la iglesia no se puede tomar fotos. Este ritual no es para el turista" (Turista italiana, entrevista personal, 8 ago. 2016), "Esta gente no es católica, no hay sacramentos. ¿El chamán está bien visto?» (Turista italiana, entrevista personal, 8 ago. 2016), "Es muy fuerte, el ambiente con las velas y todo, hay mucho humo" (Turista español, entrevista personal, 21 jul. 2016).

La ritualidad chamula no se representa únicamente para el público observador, ni las curaciones, plegarias y cantos a los santos son escenificaciones, copias o simulacros representados para observadores externos. Al contrario, son expresiones simbólicas de un mundo legítimo indígena que, a pesar de ser presentado como culturalmente inmutable, se halla incrustado en el presente contemporáneo y posee múltiples transformaciones asociadas al turismo. Prueba de ello es la continua llegada de visitantes y las reacciones como actos teatralizados que se producen por tal invasión. Ahora también hay pulsadores que ofrecen servicios de limpias a los turistas y han apareci- 
do guías propios que te relatan las características particulares de sus rituales. El turismo ya se ha convertido en una actividad cotidiana para sus habitantes y paralelamente se ha creado un mercado de alimentos y bebidas, postales, guías y souvenirs turísticos (Figura 7). Muchos de ellos esperan a los autobuses para poder sacar más recursos y la competencia se establece por llevarse más turistas y ofrecer mejores servicios: "Bendito dios, todo bien. Nos fue bien, agarramos 30 personas. Pero imagínese usted cuanto nos pagaron, ¡200 pesos!, y estaba yo peleando por los 200, quería yo 300. Ojalá que nos vaya bien a todos" (Guía chamula, entrevista personal, 30 jul. 2016).

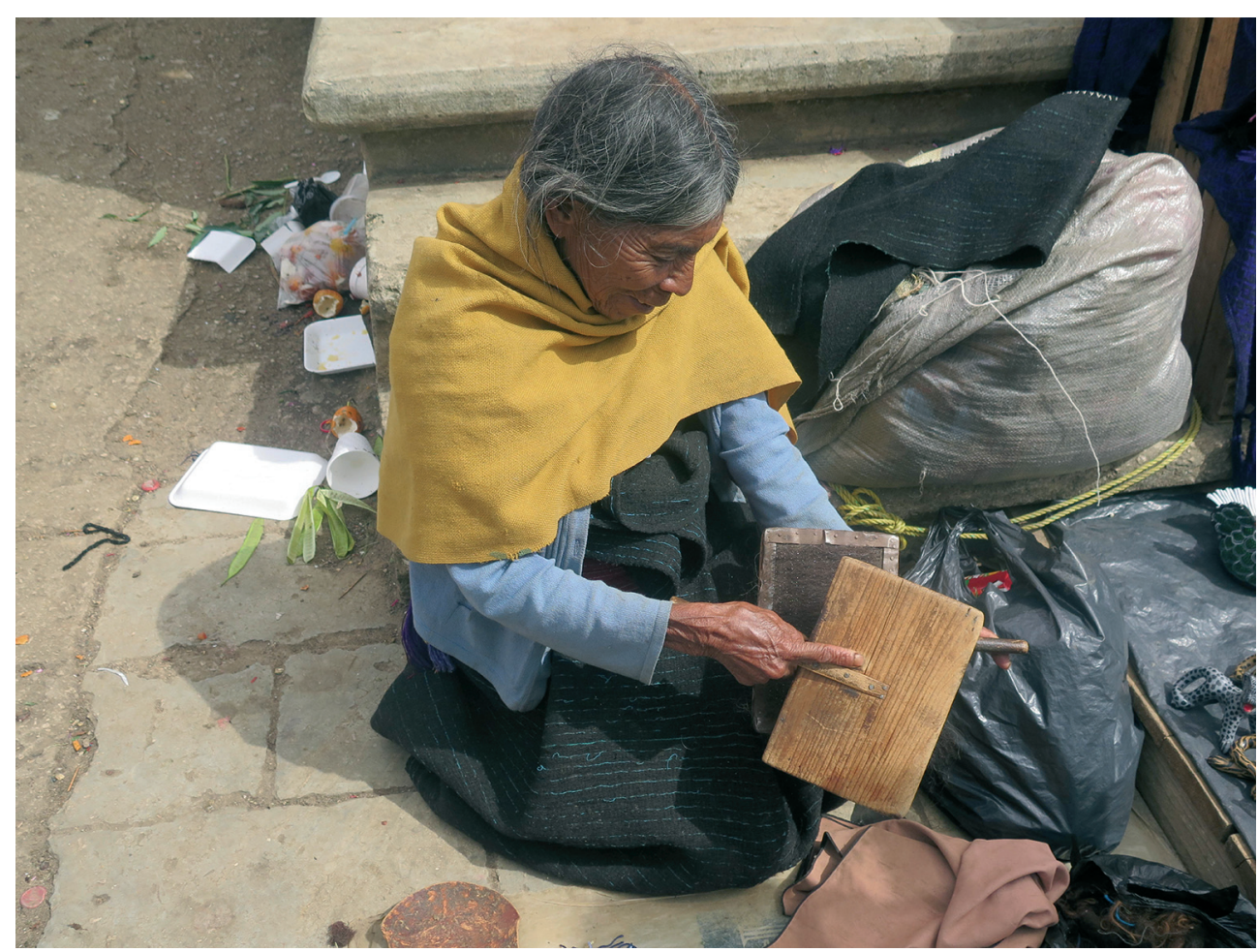

FiguRA 7.-Vendedora indígena en San Juan Chamula. Foto: Eugenia Bayona

Además, el mayor privilegio ante la llegada del turismo no viene solo por conseguir recursos, ni por vender su propio estilo de vida, sino también por haber conseguido conquistar una representación de su propia otredad en los espacios modernos de consumo.

\section{EL TOUR DE LOS TEXTILES EN ZINACANTÁN}

La ruta del municipio tsotsil de Zinacantán está planificada para acercarse a la actividad artesanal de las mujeres indígenas. Sus casas particulares se han convertido 
en pequeñas tiendas y museos de textiles y también, en lugares donde se exhibe la técnica del telar de cintura para confeccionar textiles. Se visita la cocina y otros espacios privados y los turistas experimentan con la vida cotidiana indígena. Aquí la interacción se ha construido desde un ámbito privado y particular, en un espacio fuertemente feminizado, puesto que son las mujeres las encargadas de atender a los turistas y las que consiguen importantes recursos económicos. Al contrario, los hombres son agricultores o transportistas y algunos de ellos se dedican al cultivo de flores que venden en mercados nacionales, e incluso, internacionales. Otros, sin embargo, dependen del trabajo asalariado en otras regiones de Chiapas, otros estados de la república mexicana o se han visto forzados a efectuar una migración prolongada hacia el país vecino de Estados Unidos. Los hombres son también los encargados de ostentar los cargos político-religiosos dentro de un sistema estratificado cuyo nombramiento y acceso se halla en manos, en su mayoría, de una élite indígena aliada del Partido Revolucionario Institucional (PRI), que se beneficia de estos cargos para acrecentar su riqueza y poder en el municipio (Rus y Collier 2002).

Las mujeres zinacantecas, a quienes les está negada la participación política y ritual en el municipio, se han convertido en la parte más demandada del turismo. El auge del nuevo mercado artesanal ha atraído un mayor número de familias a esta actividad y ha implicado una nueva organización del trabajo para tejer el mayor número de piezas: mujeres que se dedican exclusivamente a tejer y derivan los trabajos familiares a otras mujeres, un apoyo mutuo para conseguir tener más tiempo libre para confeccionar las piezas, o la incursión de un mayor número de miembros femeninos en la producción para pasar de pequeños talleres domésticos a talleres familiares más amplios. Incluso, se han incorporado hombres al trabajo textil para conseguir algún ingreso, aunque las piezas acabadas siempre van a salir con sello femenino. También han aparecido asociaciones de mujeres y hombres jóvenes que forman talleres de producción y venta de productos innovadores elaborados exclusivamente para el turismo y para una exportación internacional. Se están dando casos de mujeres jóvenes que prefieren quedarse solteras para dedicarse a ser tejedoras a tiempo completo y tener una mayor libertad para salir de su comunidad y comercializar sus productos en ferias locales y nacionales. Las mujeres viudas o solteras jefas de familia utilizan el trabajo artesanal como un recurso viable para la estrategia doméstica. Por su parte, las mujeres casadas se han convertido en piezas clave para la sobrevivencia familiar y han conseguido cierto reconocimiento familiar y local, aunque las negociaciones con los hombres continúan siendo complejas. Además, los procesos de migración masculina han provocado que en algunos ámbitos domésticos sean las mujeres las que acumulen capital e inviertan en sus negocios frente a otras familias donde la mujer depende todavía de las decisiones masculinas y no puede actuar con tanta libertad en sus negocios.

La interacción con el turista se realiza mediante códigos de diferencia cultural y de género. Por ejemplo, la visita a una casa de artesanas posee una carga de teatralidad, puesto que se enseña solo partes de la vivienda que se ajustan más al esquema atemporal de una casa indígena: hay un altar con figuras de santos, velas, copales con incienso y flores; en algunas casas hay fotos de familiares vestidos con el traje tradicional de mayordomo; en las salas principales se exhiben para la venta todo tipo de textiles típicos de la zona; y la cocina se halla decorada con utensilios y alimen- 
tos tradicionales como el maíz, la prensa para formar las tortillas o el comal para cocerlas. Allí se sirve un pequeño almuerzo a los turistas a base de tortillas hechas a mano, frijoles, queso y algunas salsas y especias (Figura 8). Las mujeres que reciben a los turistas llevan hermosos trajes, con faldas y blusas de flores de diferentes colores y se habla de tradiciones antiguas y de trajes autóctonos que han perdurado de generación en generación. Una de las mayores atracciones consiste en ver tejer a una mujer, mientras el guía explica las técnicas antiguas del telar de cintura, los adornos con animales prehispánicos y el enorme tiempo que se requiere para la elaboración de un textil (Figura 9). Con la visita a la casa también se incorpora el ritual de vestir a los turistas con el traje zinacanteco de boda para que, por un día, los visitantes puedan participar en un auténtico rito indígena: "Pasen por aquí por favor. A usted la vamos a poner de madrina, a ese señor lo vamos a poner de padrino y después los vestimos a ellos de novios" (Guía turístico, entrevista personal, 21 jul. 2016).

Este nicho artesanal que han construido las mujeres implica una mercantilización de sus tradiciones que, aunque resignificada en el nuevo contexto, requiere del trabajo conjunto de todos los miembros femeninos. Se ha efectuado un pacto con guías turísticos para atraer a los visitantes y en su recibimiento trabajan las abuelas, madres e hijas. Especialmente las mujeres de mayor edad y destreza son la que exhiben su técnica del telar, mientras las más jóvenes sirven en la cocina o se encargan de ofre-

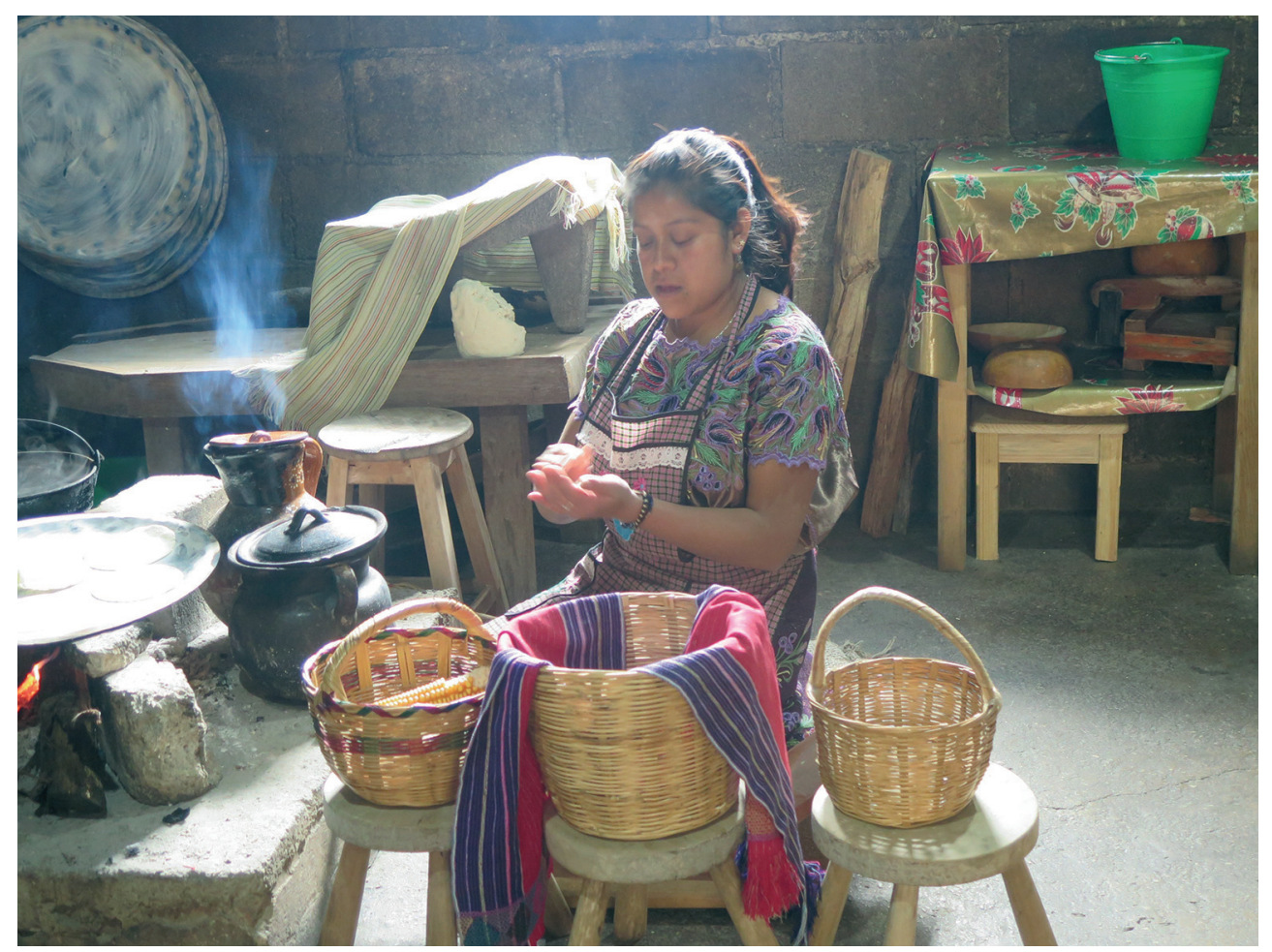

FIGURA 8.- Interior de la cocina en una casa/tienda en Zinacantán. Foto: Eugenia Bayona 


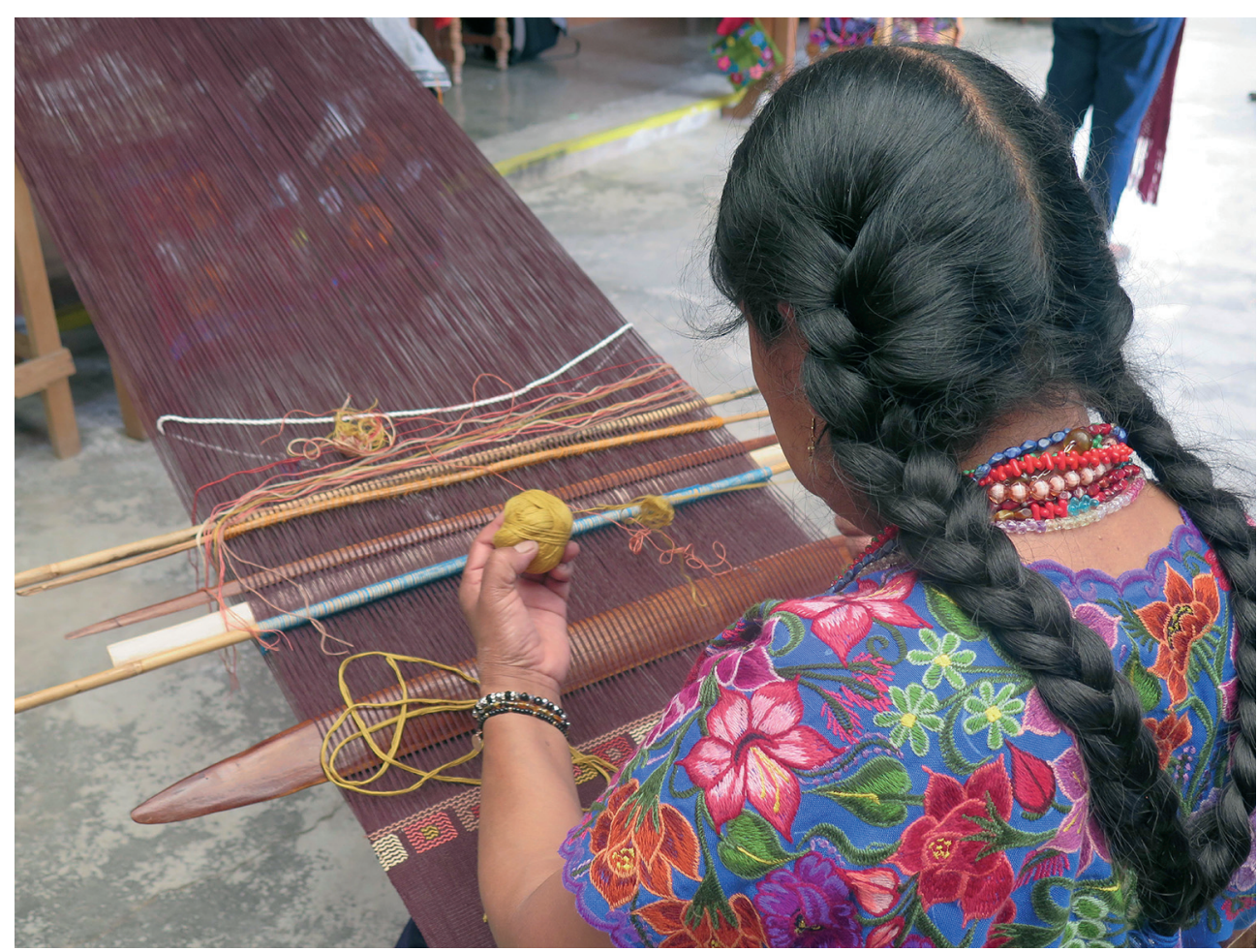

FIgurA 9.--Tejedora exhibiendo el telar de cintura en Zinacantán. Foto Eugenia Bayona

cer la mercancía a la venta. A primera vista parece que los hombres no participan en este comercio de la tradición, puesto que pocos aparecen por la vivienda en las horas de visita del tour. De hecho, la tradición artesanal pertenece a la esfera doméstica y es una tarea tradicional exclusivamente femenina. Hay además un proceso de socialización importante de madres que enseñan a sus hijas desde pequeñas la técnica de hilar y tejer la prenda. Sin embargo, los trajes que portan ahora nada tienen que ver con sus antecesores; se han incorporado nuevos colores por la nueva gama de hilos que procede de otras partes de México y de Guatemala; los diseños han sido creados gracias al apoyo recibido con asesores y materiales de organismos nacionales, estatales y también de ONG internacionales. Por eso, el traje actual de nueva creación representa un nuevo símbolo identitario: las flores se cultivan y venden, sirven para la indumentaria tanto femenina como masculina y se ha convertido en el emblema étnico por excelencia. De hecho, muchas de las mujeres indígenas que viven en la ciudad llevan estos mismos trajes, por lo que también se están convirtiendo en una importante insignia pan-indígena en San Cristóbal.

Las zinacantecas han convertido su artesanía en mercancía de venta y se representan ante los turistas a través de los objetos que confeccionan y venden. Ellas mismas son una extensión del objeto turístico como símbolo de autenticidad y sus textiles se convierten en esencias más que objetos (Santana 1997). Con el turismo, además, 
han sido capaces de conservar una técnica de telar que hubiera acabado siendo absorbida por la producción industrial, más barata y de mayor acceso (Cohen 1988). Ahora sus trajes son motivo de elogio o de interés turístico, y se pueden vender en muchas partes de la región. También es cierto que no todos los textiles en venta han sido confeccionados por la familia anfitriona. Muchos de ellos proceden de otros municipios de Los Altos, o de otros países como la vecina Guatemala, Ecuador o Perú, y han sido confeccionados por infinidad de tejedoras invisibles. Algunos textiles, efectivamente, se han elaborado en el telar de cintura, otros incorporan técnicas a máquina o bordados posteriores, e incluso, han sido producidos en maquila, con piezas iguales que salen al mercado como si fueran singulares (Figura 10). Las prendas también se han adaptado al gusto del consumidor externo y, además de las faldas y blusas indígenas con una gran variedad de colores, se confeccionan manteles, tapetes, cojines o bolsos.

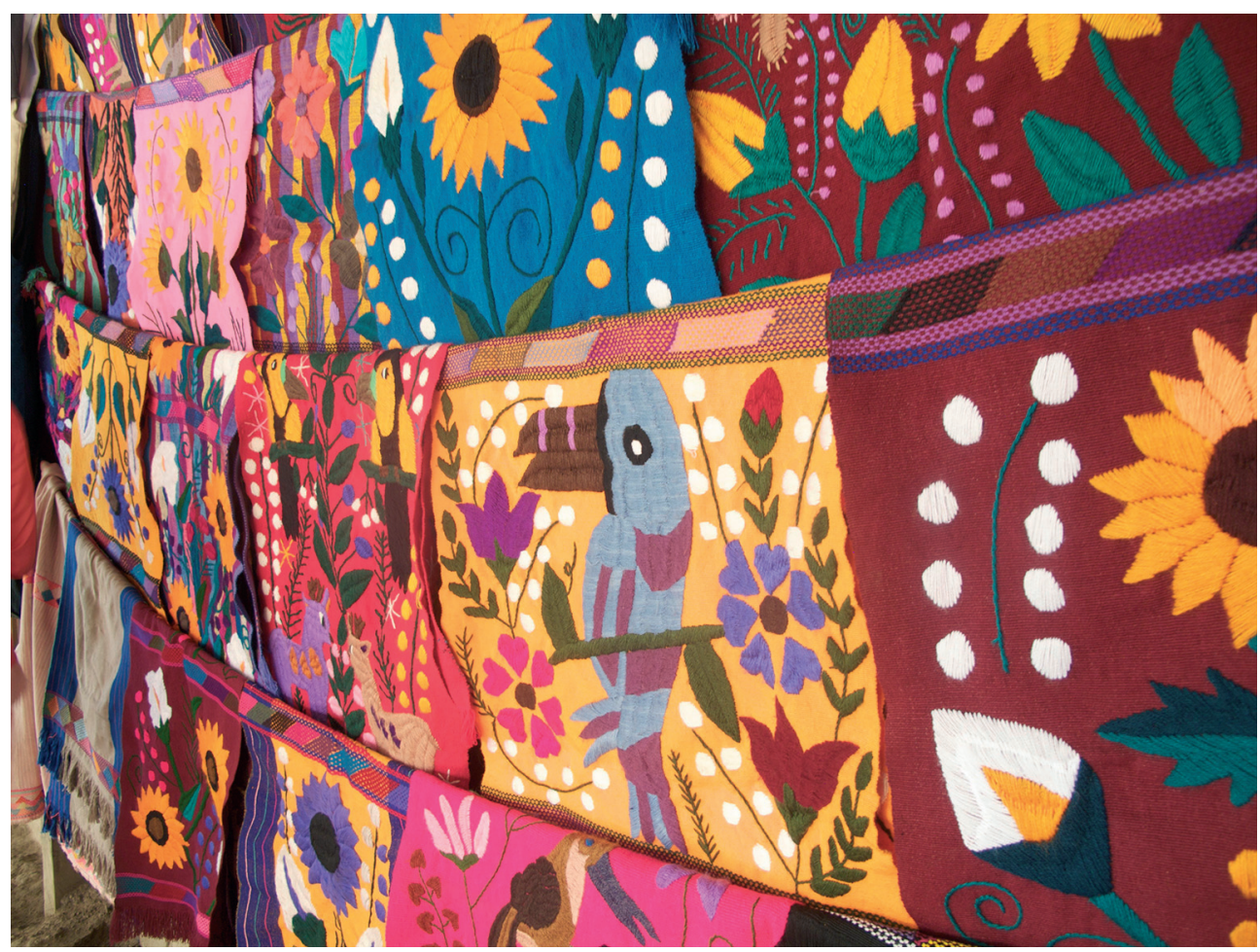

FIgurA 10.-Textiles de Zinacantán. Foto: Eugenia Bayona

La interacción con el turista es mucho más abierta y permitida que en el vecino municipio de San Juan Chamula. Prueba de ello es que las mujeres ofrecen sus propias ropas para que los visitantes prueben a ser indígenas, se ofrece comida y bebida, se posa ante las cámaras e, incluso, pueden dejar que algunos de ellos intenten probar pasar hilos en el telar de cintura. Las técnicas de venta empiezan desde el 
momento que los turistas entran en el domicilio: "¿Va a llevar la bolsa? ¿Qué va a llevar? ¿No le gustaría un centro de mesa?, si le gusta le puedo dejar a buen precio" (Vendedora zinacanteca, entrevista personal, 21 jul. 2016).

Se requiere este acercamiento para obtener recursos económicos, aunque en algunos casos haya ciertas dudas por parte del turista sobre lo que compra: ¿Es lo único que puede uno ahí comprar? ¿No vamos a ir a otra parte?» (Turista mexicano, entrevista personal, 21 jul. 2016); "Oye, y como sé que una cosa es auténtica y otra cosa no" (Turista italiana, entrevista personal, 8 ago. 2016); "Esto parece de Guatemala, ¿lo hacen ustedes?» (Turista española, entrevista personal, 30 jul. 2016).

Se cuestiona una autenticidad comercializada demasiado ordenada y artificial. Sin embargo, el escenario se autentifica porque las mujeres vendedoras acentúan sus diferencias exaltando sus trajes característicos o realizando incluso algunas partes del proceso de elaboración del producto. Además, para el turista la visita incluye tanto observación como participación, y esta experiencia se mide por la posibilidad de entrar en un espacio privado (un espacio considerado como trasero y de difícil acceso) para allí sentirse un poco indígena y también fotografiarse a gusto en su entorno.

Esta interacción entre invitado/anfitrión tiene consecuencias en ambos lados. Los turistas experimentan con una vida indígena que cada día incorpora más participación, mientras las tejedoras cumplen roles a la vez que amplían sus expectativas económicas y de protagonismo social. Lo anterior se refleja en el valor que ahora las mujeres zinacantecas conceden a los visitantes y en cómo han cambiado las vidas. Su actuación va más allá de una escenificación turística. Las casas de las anfitrionas han sido modificadas para las visitas turísticas, aunque constituyen igualmente su espacio de vida cotidiano, en las visitas se esconden objetos (como televisores, radios, cocinas modernas o lavadoras), se han construido baños para los turistas que son aprovechados por todos los miembros, se acumulan textiles por todas partes para ser expuestos en las visitas, se acomodan salones o cocinas para ofrecer comidas y las actividades diarias de las mujeres giran en torno a confeccionar textiles o a conseguir mercancía en otras casas y lugares. Las mujeres no son solo tejedoras que exhiben su rol como figura turística, son comerciantes natas que buscan, regatean y compran esos objetos calificados ahora como arte étnico. La venta de su estilo de vida no es el único motivo que les ha favorecido para entrar en el negocio del turismo, sino también el haber conservado la técnica del telar y haber encontrado un nicho próspero que les permita la reproducción económica de la familia. Quienes han tenido más éxito han podido ampliar su mercancía y algunas son ahora reconocidas como artesanas de renombre que viajan fuera de su comunidad para exhibir y vender sus tejidos. El turismo les ha permitido cierto éxito comercial y también social, puesto que son pieza esencial para la sobrevivencia familiar, aunque para ello tengan que representar su antiguo rol femenino asociado al ámbito doméstico y hayan tenido que dejar el espacio público y las decisiones comunales a los hombres.

\section{REFLEXIONES FINALES: INTERACCIONES Y REPRESENTACIONES}

Los tres casos estudiados incorporan nuevas formas de interacción turista/indígena donde corren imaginarios que son negociados y utilizados de muy diversas for- 
mas. Los turistas experimentan con una autenticidad construida donde los imaginarios visuales tienen una carga importante y viajan a través del tiempo y el espacio; lo histórico y tradicional opuesto a su presente de modernidad. También disfrutan de sus paseos, hacen compras para sus allegados y autentifican su estancia a través del contacto visual y sensorial. Aquí la corporeidad tiene más peso que el cuestionar la veracidad del acto; al fin y al cabo, se ha viajado para disfrutar del escenario de alteridad mientras se experimenta con ese Otro tan alejado de su vida cotidiana. Por su parte, los indígenas cumplen con estereotipos turísticos y se apropian de los mismos para su propia reproducción económica y social. A la vez, se construyen de manera interactiva en estas zonas de frontera transnacionales, en estos espacios turísticos donde se exhibe y se negocia la diversidad cultural (Little 2008).

Cada uno de los espacios, además, ofrece contactos diferentes Esta no ha sido una estrategia de la industria turística, sino que obedece a una evolución particular de los participantes implicados. Las rutas del mundo colonial mezclan ahora patrimonio con diversidad cultural, a pesar de la oposición de los ladinos, y en los municipios de alrededor se muestra una cultura sagrada y tradicional seleccionada por los propios protagonistas. También las formas de acercamiento son diferentes. En la ciudad el contacto del turista se diluye entre mercados y calles y se convierte en uno más en la dinámica cotidiana urbana. Aquí es un turista que se encuentra con muchos otros y de diversas nacionalidades. Aquí consume personas, objetos, ocio y diversión en una ciudad que se trasforma por las noches en un espectáculo de música y arte. En cambio, en las rutas a los municipios indígenas el contacto es más cercano, el turista forma parte de un grupo específico y observa y participa. Pareciera que una buena parte del éxito se basa en la brevedad del viaje y en los contactos esporádicos realizados que implican mayor atención. Aquí el turista es un ser individual que explica de donde viene, sus intereses, sus expectativas y sus recorridos anteriores y posteriores, y siente conjuntamente con otros turistas una gran concentración de símbolos e imágenes visuales. Su condición de turista le viene por ese espacio de interacción permitido y abiertamente participativo que le permite fantasear con la diversidad cultural.

Los turistas recorren espacios con imaginarios diferentes y a veces contradictorios; en la ciudad se viaja hacia el pasado colonial con una población indígena presente que vive del negocio del turismo. Aquí el imaginario de tradición indígena contrasta con la vida urbana pobre y marginal de una población supuestamente exótica. Los turistas observan la diversidad cultural en los mercados, pero no ven que las personas que trabajan en los hoteles también son indígenas que ocultan su identidad para trabajar en el campo del turismo. En sus viajes a los dos municipios indígenas se mueven entre un imaginario comunitario de relaciones solidarias y tradiciones ancestrales frente a inevitables transformaciones presentes. Es cierto que el escenario en las casas de las tejedoras zinacantecas cumple con sus estereotipos, pero también hay un excesivo impulso a la venta y los mismos objetos textiles son expuestos en otros lugares turísticos. También, en San Juan Chamula la vida sagrada es una visión impactante del exotismo indígena y representa una clara oposición a la religión católica, pero también contrasta con la pobreza del lugar y de sus gentes. No hay, sin embargo, un interés profundo por parte del turista en conocer sus historias particulares de lucha y oposición en el pasado ni las causas de la marginación social. En to- 
dos los casos los turistas deben acoplarse a los nuevos imaginarios y negociar significados: la pobreza del indígena frente a los hoteles de lujo, su imagen global por la utilización de objetos trasnacionales, su pequeña historia de revolución zapatista o su inserción en un mercado capitalista entre otros. Como turistas del mundo postmoderno, observan la diversidad desde la perspectiva del contacto, en algunos casos postulando que las influencias externas pueden ser positivas o negativas, y reconstruyendo la historia particular de los indígenas de Chiapas en el presente. No hay cuestionamiento sobre las relaciones de poder ocultas, solo una imagen de un exótico pacífico, de alguna forma domesticado como afirma Oehmichen (2013), que se mueve ahora entre la tradición y la globalización.

Para los indígenas, su presencia turística tiene un mayor peso. Pensemos por un momento lo que implica dicha participación en un contexto urbano históricamente marginal para los indígenas. La inserción laboral en la capital ha requerido de una identificación panindígena en la que se conjugan símbolos e identidades de varios municipios. Lo que los vincula a la ciudad no es una inserción social, ni su escasa participación en las instituciones urbanas, sino su unión como indígenas urbanos que viven en las mismas colonias y sobreviven de los mismos trabajos. El turismo ha venido a fortalecer esta presencia y los ha convertido en el objeto de consumo más apreciado. Especialmente las mujeres encarnan esos cuerpos étnicos que exhiben tradición y diferencia y son utilizadas como mercadotecnia turística y como símbolo de la autenticidad que busca el turista. Ellas mismas utilizan todas estas imágenes para vender sus mercancías por las calles y en mercados ambulantes. Pero no todas consiguen sacar los mismos beneficios y pueden ser abiertamente discriminadas por las autoridades municipales. Las luchas encarnizadas por conseguir espacios de venta y objetos atrayentes demuestran que el comercio turístico es una de las pocas alternativas de trabajo informal y sumergido. Al contrario, para los turistas los indígenas urbanos son el testimonio de ese mundo diverso y diferente que han venido a observar. Pocos conocen las historias de luchas y discriminación que hay detrás, ni tampoco que muchos de ellos provienen de diversos orígenes. Aquí el imaginario indígena se condensa y se homogeniza porque todos son indígenas y todos representan la diversidad cultural. Sin saberlo, el turista está contribuyendo a la presencia indígena en la ciudad.

Los casos de Chamula y Zinacantán son diferentes e implican cierto empoderamiento indígena y control sobre lo representado. En ambos casos la representación de la cultura va ligada a la reproducción económica, pero no se efectúa de la misma forma ni tiene las mismas repercusiones sociales; en términos económicos ha favorecido a algunos sectores más que otros y hay un gran abismo de participación por género entre ambos municipios. Las imágenes que proyectan uno y otro son fragmentadas y representan selecciones que algunos grupos en el poder o familias bien acomodadas consideran importantes. Por ejemplo, en el caso de Chamula la iglesia se convierte en el lugar adecuado para la exhibición de la otredad puesto que cumple perfectamente con los estereotipos étnicos. Pareciera que todos los cambios que están aconteciendo entre los jóvenes chamulas, la búsqueda de nuevas formas de vida más cercana a la modernidad, queden invisibilizados por el escenario que se presenta en la iglesia. De alguna forma, la puesta en escena de la vida sagrada sirve para legitimar los intereses políticos enmascarados de la élite indígena. Para los turistas, el 
tour en Chamula es quizás el que más cumple con las expectativas por visibilizar un espacio sagrado, extraño y exótico. Hay motivos para pensar que la masificación del turismo en la iglesia podría cuestionar su validez, aunque la cantidad de símbolos condensados hace imposible su falsedad. Al fin y al cabo, la entrada al recinto implica el traspaso a la frontera de lo desconocido y misterioso lleno de humo, velas e incienso. Aquí la falsedad de la actividad turística parte del propio chamula que cuestiona para qué sirve tanto gasto y consumo occidental. En los últimos años, las élites gobernantes se han cuestionado si es necesario exhibir su sacralidad ante los turistas, lo que demuestra que este poder ya no requiere de observadores externos sino de los mecanismos eficaces de control y legitimación que utilizan por otras vías.

En Zinacantán, al contrario, se puede pensar en un proceso creciente de mujeres como protagonistas en el turismo que reclaman espacios de igualdad económica y equidad social. Son mujeres que tienen casas en el centro de la cabecera del municipio y por ello, son más privilegiadas que otras que viven en los alrededores. Sus conquistas se sitúan en los propios ámbitos domésticos y familiares donde se establece una hospitalidad comercializada con el turista (Cohen 1988) para el buen funcionamiento del negocio. El empoderamiento viene precisamente por la capacidad de crear diferencia, en la utilización del lenguaje de la cultura, como sostiene Poole (2005), y en capturar los espacios adecuados para su exhibición turística. Es por eso que para el turista este pequeño mundo que incorpora partes del proceso se halla totalmente verificado, porque se realiza en un ámbito doméstico propio y legitimado por mujeres. Esta pequeña conquista femenina ha requerido del reforzamiento de una ideología familiar que organiza la división del trabajo por género. Sin embargo, lo doméstico ha traspasado sus fronteras y ahora las mujeres compran y venden en sus casas y fuera de ellas. Quizás por eso, muchas jóvenes tejedoras se cuestionan si se deben casar o no, porque la reproducción económica ya la tienen asegurada y este oficio les permite salir al ámbito público más allá de sus límites municipales.

Todas estas representaciones turísticas tienen repercusiones y significan conquistas reales que se extienden a otras esferas sociales. La falta de inversiones y programas institucionales para enfrentar la marginación y la pobreza obliga al colectivo indígena a participar en actividades informales alrededor del turismo. Se han tratado tres espacios indígenas conquistados que no son únicos ni implica que el resto de la población en Los Altos se halle en la misma situación. Al contrario, si consideramos el contexto en el que están inmersos, con índices de marginación alarmantes y con pocas oportunidades laborales, la venta de la cultura se ha convertido en un medio de vida único y esencial para la sobrevivencia. Más bien hay que observar estas conquistas como respuestas contextuales en un entorno difícil y en lugares donde todavía impera la distinción jerárquica mestiza e indígena. Son espacios ganados con esfuerzo que han requerido de luchas y negociaciones con significados diferentes en cada ámbito; son una abierta denuncia ante su discriminación étnica en San Cristóbal, se convierten en un arma política para las élites chamulas o en una vía de empoderamiento para las mujeres artesanas zinacantecas. La reproducción económica no ha sido la única causa para su protagonismo turístico, aunque puede que haya sido la primera y más importante, sino también ha permitido una reproducción simbólica que encuentra en el espacio de la comercialización de la etnicidad un lugar propicio de representación. 


\section{BIBLIOGRAFÍA CITADA}

Cantón Delgado, Manuela. 1997. "Las expulsiones indígenas en Los Altos de Chiapas: algo más que un problema de cambio religioso". Mesoamérica 18(33): 147-169.

Cohen, Erik. 1988. "Authenticity and commoditization in tourism". Annals of Tourism Research 15(3): 371-386. doi: < https://doi.org/10.1016/0160-7383(88)90028-X>.

Cohen, Erik. 2005. "Principales tendencias en el turismo contemporáneo". Política y Sociedad 42(1): 11-24. Disponible en: <http://revistas.ucm.es/index.php/POSO/article/view/POSO0505130011A>. Fecha de acceso: 30 nov. 2016.

Comaroff, John L. y Jean Comaroff. 2011. Etnicidad, S.A. Madrid: Katz Editores.

Coronado, Gabriela. 2008. "Insurgencia y turismo: reflexiones sobre el impacto del turista politizado en Chiapas". Pasos. Revista de Turismo y Patrimonio Cultural 6(1): 53-68. doi: <https://doi.org/ 10.25145/j.pasos.2008.06.005>.

Cruz Salazar, Tania. 2017. "Lo etnojuvenil. Un análisis sobre el cambio socio-cultural entre tsotsiles, tzeltales y choles". Liminar. Estudios Sociales y Humanísticos 15(1): 53-67.

Graburn, Nelson. 1992. "Turismo: El Viaje Sagrado", en Valene S. Smith (comp.), Anfitriones e invitados. Antropología del Turismo: 45-68. Madrid: Endymion.

Greenwood, Davyd J. 1992. "La cultura al peso: perspectiva antropológica del turismo en tanto proceso de mercantilización cultural", en Valene S. Smith (comp.), Anfitriones e invitados. Antropología del Turismo: 257-280. Madrid: Endymion.

Hvostoff, Sophie. 2004. "Indios y coletos: por una relectura de las relaciones interétnicas en San Cristóbal de Las Casas", en Maya Lorena Pérez Ruiz (coord.), Tejiendo historias. Tierra, género y poder en Chiapas: 297-320. México: Instituto Nacional de Antropología e Historia.

INEGI [Instituto Nacional de Estadística, Geografía e Informática]. 2010. Censo de Población y Vivienda. Disponible en: <http://www.inegi.org.mx>. Fecha de acceso: 15 ene. 2018.

INEGI [Instituto Nacional de Estadística, Geografía e Informática]. 2016. Anuario estadístico y geográfico de Chiapas. Disponible en: <http://www.datatur.sectur.gob.mx/ITxEF_Docs/ CHIS_ANUARIO_PDF16.pdf > . Fecha de acceso: 15 ene. 2018.

Little, Walter E. 2008. "Living within the Mundo Maya Project. Strategies of Maya Handicrafts Vendors". Latin American Perspectives 35(3): 87-102. doi: <https://doi.org/10.1177/0094582X08315793>.

MacCanell, Dean. 2003. El turista, una nueva teoría de la clase ociosa. Barcelona: Melusina.

Morquecho, Gaspar. 1992. Los indios en proceso de organización. La organización indígena de Los Altos de Chiapas, Criach. México: Universidad Autónoma de Chiapas.

Neila Boyer, Isabel. 2012. "Ach'Kuxlejal (nuevo vivir). Amor, carácter y voluntad en la modernidad tzotzil", en Pedro Pitarch y Gemma Orobitg (eds.), Modernidades Indigenas: 281-319. Madrid/ Fráncfort: Iberoamericana/Vervuert.

Oehmichen, Cristina. 2013. "Introducción", en Cristina Oehmichen (ed.), Enfoques antropológicos sobre el turismo contemporáneo: 11-33. México D. F.: Universidad Autónoma de México.

Paris Pombo, María Dolores. 2000. "Identidades excluyentes en San Cristóbal de Las Casas". Disponible en <http://www.redalyc.org/articulo.oa?id=15905805>. Fecha de acceso: 15 ene. 2018.

Pineda, Luz O. 1995. "Maestros Bilingües, burocracia y poder político en Los Altos de Chiapas", en Juan Pedro Viqueira y Mario Humberto Ruz (eds.), Chiapas. Los rumbos de otra historia: 279-300. México: UNAM/CIESAS/CEMCA/UDEG.

Poole, Deborah. 2005. "Diferencias ambiguas: memorias visuales y el lenguaje de la diversidad en la Oaxaca posrevolucionaria". Revista Mexicana de Ciencias Politicas y Sociales 195: 125-162. Disponible en: <http://www.redalyc.org/articulo.oa?id=42119506>. Fecha de acceso: 15 ene. 2018.

Ramos, Teresa. 2004. "Artesanas y artesanías: indígenas y mestizas de Chiapas construyendo espacios de cambio". Liminar. Estudios Sociales y Humanísticos 2(1): 50-71.

Ramos, Teresa. 2010 Artesanías tzeltales. Entrecruces de cooperación, conflicto y poder. México: Universidad de Ciencias y Artes de Chiapas, UNICACH.

Robledo, Gabriela. 1997. Disidencia y religión. Los expulsados de San Juan Chamula. México: Universidad Autónoma de Chiapas.

Robledo, Gabriela. 2009. "Vivir en la ciudad...La migración rural urbana en el altiplano chiapaneco", en Graciela Freyermunt y Sergio Meneses (coords.), De crianzas, jaibas e infecciones. Indigenas del sureste en la migración: 109-142. México: CIESAS. 
Rus, Diana y Jan Rus. 2008. "La migración de trabajadores indígenas de Los Altos de Chiapas a Estados Unidos, 2001-2005: el caso de San Juan Chamula", en Daniel Villafuerte Solís y María del Carmen García Aguilar (coords.), Migraciones en el sur de México y Centroamérica: 343-382. México: Universidad de Ciencias y Artes de Chiapas, UNICACH/Porrúa.

Rus, Jan. 1995. "La comunidad revolucionaria institucional: la subversión del gobierno indígena en Los Altos de Chiapas 1936-1968", en Juan Pedro Viqueira y Mario Humberto Ruz (eds), Chiapas. Los rumbos de otra historia: 251-277. México: UNAM/CIESAS/CEMCA/UDEG.

Rus, Jan y George A. Collier. 2002. "Una generación de crisis en Los Altos de Chiapas: Los casos de Chamula y Zinacantán, 1974-2000", en Shannan L. Mattiace, Rosalva Aída Hernández y Jan Rus (eds.). Tierra, libertad y autonomía: Impactos regionales del zapatismo: 157-199. México: CIESAS.

Salazar, Noel B. 2012. "Tourism Imaginaries: A Conceptual Approach". Annals of Tourism Research 39(2): 863-882. doi: <https://doi.org/10.1016/j.annals.2011.10.004>.

Santana, Agustín. 1997. Antropología del turismo. ¿Nuevas hordas, viejas culturas? Barcelona: Ariel.

Smith, Valene S. 1992. "Introducción", en Valene S. Smith (comp.), Anfitriones e invitados. Antropologia del Turismo: 15-41. Madrid: Endymion.

Urry, John. 2002. The Tourist Gaze. Londres: Sage.

Van den Berghe, Pierre L. 1994. The Quest of the Other. Ethnic Tourism in San Cristóbal, México. Seattle: University of Washington Press.

Van den Berghe, Pierre L. 1995 "Marketing Mayas. Ethnic Tourism Promotion in Mexico". Annals of Tourism Research 22(3): 568-588. doi: <https://doi.org/10.1016/0160-7383(95)00006-R>.

Viqueira, Juan P. 1995. "Los Altos de Chiapas: una introducción general", en Juan Pedro Viqueira y Mario Humberto Ruz (eds.), Chiapas. Los rumbos de otra historia: 219-236. México: UNAM/CIESAS/ CEMCA/UDEG.

Viqueira, Juan P. 2002. Encrucijadas chiapanecas. Economía, religión e identidades. México: Tusquets Editores.

Wang, Ning. 1999. "Rethinking Authenticity in Tourism Experience". Annals of Tourism Research 26(2): 349-70. doi: <https://doi.org/10.1016/S0160-7383(98)00103-0>.

Fecha de recepción: 26 de mayo de 2017

Fecha de aceptación: 15 de diciembre de 2017 